\title{
ADIPOSE-TISSUE-DERIVED THERAPEUTIC CELLS IN THEIR NATURAL ENVIRONMENT AS AN AUTOLOGOUS CELL THERAPY STRATEGY:THE MICROTISSUE-STROMAL VASCULAR FRACTION
}

\author{
S. Nürnberger ${ }^{1,2,4}$, C. Lindner ${ }^{1,2}$, J. Maier ${ }^{1,2}$, K. Strohmeier ${ }^{1,2,5}$, C. Wurzer ${ }^{1,2,3}$, P. Slezak ${ }^{1,2}$, S. Suessner ${ }^{2,6}$, \\ W. Holnthoner ${ }^{1,2}$, H. Redl ${ }^{1,2}$, S. Wolbank ${ }^{1,2,}$ and E. Priglinger ${ }^{1,2, \S, *}$ \\ ${ }^{1}$ Ludwig Boltzmann Institute for Experimental and Clinical Traumatology, AUVA Research Centre, \\ Linz/Vienna, Austria \\ ${ }^{2}$ Austrian Cluster for Tissue Regeneration, Vienna, Austria \\ ${ }^{3}$ Liporegena $\mathrm{GmbH}$, Breitenfurt, Austria \\ ${ }^{4}$ Department of Orthopedics and Trauma-Surgery, Division of Trauma-Surgery, \\ Medical University of Vienna,Vienna, Austria \\ ${ }^{5}$ School of Medical Engineering and Applied Social Sciences, \\ University of Applied Sciences Upper Austria, Linz, Austria \\ ${ }^{6}$ Red Cross Blood Transfusion Service of Upper Austria, Linz, Austria \\ $\S$ These authors contributed equally
}

\begin{abstract}
The prerequisite for a successful clinical use of autologous adipose-tissue-derived cells is the highest possible regenerative potential of the applied cell population, the stromal vascular fraction (SVF). Current isolation methods depend on high enzyme concentration, lysis buffer, long incubation steps and mechanical stress, resulting in single cell dissociation. The aim of the study was to limit cell manipulation and obtain a derivative comprising therapeutic cells (microtissue-SVF) without dissociation from their natural extracellular matrix, by employing a gentle good manufacturing practice (GMP)-grade isolation. The microtissue-SVF yielded larger numbers of viable cells as compared to the improved standard-SVF, both with low enzyme concentration and minimal dead cell content. It comprised stromal tissue compounds (collagen, glycosaminoglycans, fibroblasts), capillaries and vessel structures (CD31 ${ }^{+}$, smooth muscle actin ${ }^{+}$). A broad range of cell types was identified by surface-marker characterisation, including mesenchymal, haematopoietic, pericytic, blood and lymphatic vascular and epithelial cells. Subpopulations such as supra-adventitial adipose-derived stromal/stem cells and endothelial progenitor cells were significantly more abundant in the microtissue-SVF, corroborated by significantly higher potency for angiogenic tube-like structure formation in vitro. The microtissue-SVF showed the characteristic phenotype and tri-lineage mesenchymal differentiation potential in vitro and an immunomodulatory and pro-angiogenic secretome. In vivo implantation of the microtissue-SVF combined with fat demonstrated successful graft integration in nude mice. The present study demonstrated a fast and gentle isolation by minor manipulation of liposuction material, achieving a therapeutically relevant cell population with high vascularisation potential and immunomodulatory properties still embedded in a fraction of its original matrix.
\end{abstract}

Keywords: Stromal vascular fraction, extracellular matrix, adipose-derived stromal/stem cells, endothelial progenitor cells, angiogenesis.

*Address for correspondence: Dr Eleni Priglinger, Ludwig Boltzmann Institute for Experimental and Clinical Traumatology, Krankenhausstraße 7, A-4010 Linz, Austria.

Telephone number: +43 6648234342 Email: Eleni.Priglinger@trauma.lbg.ac.at

Copyright policy: This article is distributed in accordance with Creative Commons Attribution Licence (http://creativecommons.org/licenses/by-sa/4.0/).

\section{Introduction}

Adipose-tissue-derived cells are successfully applied for the reconstruction and regeneration of damaged or diseased tissues where common therapies fail (Pak et al., 2018). Their high regenerative potential is underlined by several clinical trials. More preclinical studies have progressed into clinical trials, 
with mesenchymal stromal/stem cells (MSCs) derived from adipose tissue, than from other sources, e.g. the bone marrow (Macrin et al., 2017). The adipose tissue is abundantly available as an autologous cell source in most patients and provides easily obtainable regenerative cells in large amounts (Bacakova et al., 2018). The isolated cell population, the stromal vascular fraction (SVF), contains a variety of stem, progenitor and mature cell types from haematopoietic, vascular and mesenchymal origin, such as lymphocytes, monocytes/macrophages, endothelial cells, pericytes, smooth muscle cells, fibroblasts and adipose-derived stromal/stem cells (ASCs) among others (Bourin et al., 2013; Zimmerlin et al., 2010).

ASCs can be selected as one of the adherent cell fractions, by cultivating the SVF on tissue culture plastic (Bourin et al., 2013). They are characterised by their self-renewal potency and ability to give rise to at least adipocytic, osteocytic, chondrocytic and myocytic lineages (De Francesco et al., 2015; Gimble and Guilak, 2003a; Gimble and Guilak, 2003b; Zuk et al., 2002; Zuk et al., 2001). ASCs in culture express some common mesenchymal stromal/stem cell markers including CD90, CD73, CD105 and CD44 and remain negative for CD45 and CD31 (Bourin et al., 2013). During regeneration, they act as immunomodulators and can migrate to damaged areas of the body, where they secrete factors facilitating tissue repair (Bateman et al., 2018). ASCs have regenerative potential in vitro, in animal models and in clinical studies for soft tissue reconstruction, bone and cartilage regeneration, treatment of immune diseases, cardiovascular diseases, gastrointestinal diseases, neurological diseases and diabetes, with variable success (Bateman et al., 2018; Nguyen et al., 2015).

In recent years, there has been a shift towards using the total SVF cell population, following the concept of an intraoperative procedure bringing autologous cells back into the patient without further processing. In terms of cell-assisted lipotransfer (CAL), the addition of the SVF is successfully established in fat grafting, enhancing long-term graft stability (Gentile et al., 2012; Jiang et al., 2015). With its potential for immunomodulation and angiogenesis, the SVF recruits vessels and induces a local regulatory, proregenerative immune cell phenotype (reviewed by Stivers et al., 2017). Providing a clinical grade product is a critical requirement for ASC or SVF application. In contrast to the SVF, ASCs depend on in vitro expansion, which is associated with challenges such as possible cell transformation risks or stemness loss (Jiang et al., 2017; McIntosh K., 2006; Pan et al., 2014; Safwani et al., 2013). Moreover, using the SVF during a surgical procedure in an autologous and homologous way is not considered an advanced therapy medicinal product (ATMP) (European Medicines Agency, 2012). Still, the multiple steps of collagenase and erythrocyte lysis buffer incubation, as well as centrifugation and filtration can negatively impact on cell efficacy (Hagman et al., 2012). Hence, there is an unmet need for a gentle isolation method providing regenerative cell populations protected by their natural environment and fulfilling all the regulatory requirements of a minimally manipulated cellular product.

The present study described a fast and particularly gentle method of SVF isolation by minor manipulation of liposuction material, achieving an SVF cell population, still embedded in a fraction of its original matrix. The microtissue-SVF was isolated from the adipose tissue with a good manufacturing practice (GMP)-certified collagenase under sterile and mild conditions and compared to the standard-SVF, both isolated with low collagenase concentration. The freshly isolated microtissue-SVF was thoroughly characterised with regards to vitality, matrix composition, cell identity and functionality. This was achieved by analysing tissue morphology, cellular composition, surface marker profile, adipogenic, osteogenic, chondrogenic and vasculogenic potential, regenerative secretome protein profile and support of graft integration after intramuscular injection in nude mice. Since adipose tissue consists of various extracellular matrix (ECM) components, together with a variety of therapeutic cells (Liu et al., 2011), the working hypothesis was that adipose-derived microtissue-SVF, comprising therapeutic cells without dissociation from the adipose tissue ECM, might represent an optimised product for tissue repair.

\section{Materials and Methods}

\section{Liposuction}

The collection of human adipose tissue was approved by the local ethical board (application/approval number 200, 12.05.2005 and 19.05.2014) and written patient's consent. Subcutaneous adipose tissue was obtained from 25 patients [age: $39 \pm 10$ years; body mass index (BMI): $33.6 \pm 6.7 \mathrm{~kg} / \mathrm{m}^{2}$ ] during routine outpatient liposuction procedures under local tumescence anaesthesia.

\section{Standard-SVF isolation}

Standard-SVF isolation was optimised to obtain the highest yield of a highly viable single-cell suspension under mild proteolytic conditions. Liposuction material was collected in a fully closed container and $100 \mathrm{~mL}$ liposuction material was transferred into a blood bag (Macopharma, Langen, Germany) and washed with an equal volume of phosphate buffered saline (PBS), to remove blood and tumescence solution (Table 1). Next, for tissue digestion, PBS was replaced with $0.2 \mathrm{U} / \mathrm{mL}$ collagenase NB4 (Serva, Vienna, Austria) dissolved in $100 \mathrm{~mL}$ PBS containing $\mathrm{Ca}^{2+} / \mathrm{Mg}^{2+}$ and $25 \mathrm{mM} \mathrm{N}$-(2-hydroxyethyl)piperazineN'-(2-ethanesulfonic acid) (HEPES; Sigma-Aldrich), resulting in a final collagenase concentration of $0.1 \mathrm{U} /$ $\mathrm{mL}$. The blood bag was incubated at $37^{\circ} \mathrm{C}$ under 
Table 1. Overview of standard-SVF and microtissue-SVF isolation. The optimised standard-SVF isolation protocol was adapted for microtissue-SVF isolation using GMP-compliant reagents, avoiding erythrocyte lysis buffer, one extra centrifugation step and filtration.

\begin{tabular}{|c|c|c|}
\hline & Standard-SVF isolation & Microtissue-SVF isolation \\
\hline Washing I & $1 \times$ with PBS & $1 \times$ with PBS \\
\hline Collagenase & NB4, $0.1 \mathrm{U} / \mathrm{mL}, 37^{\circ} \mathrm{C}, 180 \mathrm{rpm}, 1 \mathrm{~h}$ & $\mathrm{NB} 6,0.1 \mathrm{U} / \mathrm{mL}, 37^{\circ} \mathrm{C}, 180 \mathrm{rpm}, 1 \mathrm{~h}$ \\
\hline Centrifugation I & $1200 \times g, 7 \mathrm{~min}$ & $1200 \times g, 7 \mathrm{~min}$ \\
\hline Erythrocyte lysis & Erythrocyte lysis buffer, $5 \mathrm{~min}, 37^{\circ} \mathrm{C}$ & - \\
\hline Centrifugation II & $500 \times g, 5 \mathrm{~min}$ & $1 \times$ with PBS \\
\hline Washing II & $1 \times$ with PBS & - \\
\hline Filtration & $100 \mu \mathrm{m}$ & $300 \times g, 5 \mathrm{~min}$ \\
\hline Centrifugation III & $500 \times g, 5 \mathrm{~min}$ & \\
\hline
\end{tabular}

moderate shaking $(180 \mathrm{rpm})$ for $1 \mathrm{~h}$. The digested tissue was transferred into $50 \mathrm{~mL}$ tubes. After centrifugation at $1200 \times g$ for $7 \mathrm{~min}$, the cell pellet was incubated with $100 \mathrm{~mL}$ erythrocyte lysis buffer for 5 min at $37^{\circ} \mathrm{C}$, to eliminate red blood cells. The supernatant was aspirated after centrifugation for $5 \mathrm{~min}$ at $500 \times g$. The pellet was washed with PBS and filtered through a $100 \mu \mathrm{m}$ cell strainer (Greiner). After another centrifugation step at $500 \times g$ for $5 \mathrm{~min}$, the supernatant was removed. The isolated standard-SVF was resuspended in endothelial growth medium 2 (EGM-2; Lonza) and used for further analyses.

\section{Microtissue-SVF isolation}

For microtissue-SVF isolation, liposuction material was collected in a fully closed container and $100 \mathrm{~mL}$ were transferred into a blood bag and washed with an equal volume of PBS to remove blood and tumescence solution (Table 1). Next, for tissue digestion, PBS was replaced with $0.2 \mathrm{U} / \mathrm{mL}$ collagenase NB6 (Serva) dissolved in $100 \mathrm{~mL}$ PBS containing $\mathrm{Ca}^{2+} / \mathrm{Mg}^{2+}$ and $25 \mathrm{mM}$ HEPES, resulting in a final collagenase concentration of $0.1 \mathrm{U} / \mathrm{mL}$. The blood bag was incubated at $37^{\circ} \mathrm{C}$ under moderate shaking $(180 \mathrm{rpm})$ for $1 \mathrm{~h}$. The digested tissue was transferred into $50 \mathrm{~mL}$ tubes. After centrifugation at $1200 \times g$ for $7 \mathrm{~min}$, the cell pellet was washed with PBS. After another centrifugation step at $300 \times g$ for $5 \mathrm{~min}$, the microtissue-SVF was resuspended in EGM-2 and used for further analyses.

\section{Standard-SVF and microtissue-SVF cultivation}

To analyse the differentiation potential, the isolated standard-SVF and microtissue-SVF were cultured for 1 week in EGM-2 at $37{ }^{\circ} \mathrm{C}, 5 \% \mathrm{CO}_{2}$ and $95 \%$ air humidity, allowing the adherent cell fraction, including ASCs, to outgrow as an adherent monolayer on tissue culture plastic. The cells were cultured to a sub-confluent state and detached with $1 \times$ trypsin/ ethylenediaminetetraacetic acid (EDTA, Lonza) at $37^{\circ} \mathrm{C}$. Medium was changed every 3-4 $\mathrm{d}$.

\section{Cell yield and viability quantification}

To visualise cell vitality in pure fat (liposuction material), isolated microtissue-SVF and standardSVF, calcein AM (ThermoFisher Scientific) and ethidium homodimer 1 (EthD-1; Sigma-Aldrich) were used. Pure fat and the isolated microtissue-SVF were placed into a 6-well plate, while the standard-SVF was pipetted into $15 \mathrm{~mL}$ tubes for centrifugation after each step. All 3 conditions were washed with PBS $+10 \%$ foetal calf serum (FCS; PAA Laboratories $\mathrm{GmbH}$, Pasching, Austria) and incubated at room temperature for $10 \mathrm{~min}$ in the dark with the staining solution containing calcein $\mathrm{AM}(2 \mu \mathrm{g} / \mathrm{mL})$ and EthD-1 $(1.4 \mu \mathrm{g} / \mathrm{mL})$ dissolved in PBS $+10 \%$ FCS. Next, all three conditions were washed with PBS + $10 \%$ FCS, transferred on to microscope slides and covered with cover slips. Fluorescence and brightfield/phase lens 1 (Ph1) images were acquired using a fluorescence microscope (Axiovert 200; Zeiss). For quantification of cell yield and viability after standard-SVF and microtissue-SVF isolation, cells were stained with 4',6-diamidino-2-phenylindole (DAPI) and analysed using a cell counter (NucleoCounter ${ }^{\circledR}$ NC-200 ${ }^{\mathrm{TM}}$; ChemoMetec, Allerod, Denmark) with integrated fluorescence microscope following the "Viability and Cell Count-Aggregated Cells Assay" protocol. Each sample was transferred into a Via1Cassette $^{\mathrm{TM}}$ (ChemoMetec) coated with DAPI and two measurements were performed: one with cell lysis solution, to stain all cell nuclei in the sample, and one without lysis solution, to stain only non-viable cells.

\section{Cellular adenosine triphosphate (ATP)}

To determine cell vitality, the cellular ATP concentration, was measured using the CellTiterGlo ${ }^{\circledR}$ Luminescent Cell Viability Assay (Promega) according to the manufacturer's instructions. The luminescent signal was detected with an Infinite ${ }^{\circledR}$ M200 Multimode Microplate Reader (Tecan, Grödig, Austria) at an exposure time of $2 \mathrm{~s}$ and analysed using an ATP standard curve. 


\section{Flow cytometry analysis}

Freshly isolated SVF after standard-SVF or microtissue-SVF isolation were characterised using antibodies against a number of antigens (Table 2a). Specific subpopulations were analysed through combination of the antibodies CD31, CD34, CD45-V500 Horizon (BD Biosciences), CD90, CD146, SSEA3, CD105, LYVE-1 and podoplanin (Table 2b). For staining, $5 \times 10^{5}$ cells in $50 \mu \mathrm{L}$ PBS with $1 \%$ FCS were incubated with $5 \mu \mathrm{L}$ primary labelled antibodies at room temperature for $15 \mathrm{~min}$ in the dark. Cells were washed with $1.5 \mathrm{~mL}$ Cell Wash ${ }^{\mathrm{TM}}$ (BD Biosciences, Schwechat, Austria) and centrifuged for $5 \mathrm{~min}$ at $400 \times g$. The supernatant was discarded and the cell pellet resuspended in $300 \mu \mathrm{L} 1 \times$ Cell Fix ${ }^{\mathrm{TM}}$ (BD Biosciences; diluted 1 : 10 with Aqua Dest, Fresenius Kabi, Linz, Austria). For staining with the intracellular marker $\alpha$-SMA, cells were first resuspended in $1 \times$ Cell Fix $^{\mathrm{TM}}$ and Cell Wash ${ }^{\mathrm{TM}}$ containing $0.1 \%$ Triton X-100 was used for all washing steps. $3 \mu \mathrm{L}$ of $\alpha$-SMA were added, cells were incubated at room temperature for $30 \mathrm{~min}$ in the dark and, after centrifugation for $5 \mathrm{~min}$ at $400 \times g$, resuspended in PBS. All samples were analysed using a flow cytometer (FACSCanto; BD Biosciences).

\section{Histological staining}

In vitro and in vivo standard histological samples were fixed with $4 \%$ neutral buffered formalin for $24 \mathrm{~h}$ and rinsed in PBS. Then, samples were dehydrated in graded series of ethanol, followed by xylol and embedding in paraffin. 3-4 $\mu$ m-thick sections were cut using a rotary microtome (HM355S Microm; ThermoFisher Scientific) and deparaffinised for either histochemical or immunohistochemical analysis. Microtissue-SVF and pellets were histochemically stained with alcian blue to display the glycosaminoglycan content. Subcutaneously implanted fat and microtissue-SVF-samples were stained with haematoxylin and eosin (H\&E) for overview of integration into the surrounding skin and muscles. Microtissue-SVF and pellets were immunohistochemically stained for ECM components (collagen type I, type II and type III) and cell markers [fibroblast (clone TE-7), endothelial cells (CD31) and pericytes (SMA)]. Deparaffinised sections were prepared by blocking the endogenous peroxides and alkaline phosphatase with BIOXALL ${ }^{\circledR}$ (Vector Labs); antibody retrieval was performed with steaming at $\mathrm{pH} 9.0$ (Tris-EDTA buffer) for SMA and $\mathrm{pH} 6$ (citrate buffer) for collagen type I and CD31, pepsin for collagen type II, proteinase $\mathrm{K}$ for collagen type III, fibroblasts and CD31. Then, antibodies were incubated for $1 \mathrm{~h}$ : collagen type I (Abcam) $2 \mu \mathrm{g} / \mathrm{mL}$, collagen type II (ThermoFisher Scientific) $2 \mu \mathrm{g} / \mathrm{mL}$, collagen type III (Abcam) $5 \mu \mathrm{g} /$ $\mathrm{mL}$, fibroblasts (Millipore) $0.125 \mu \mathrm{g} / \mathrm{mL}, \mathrm{CD} 31$ (DAKO) $10.25 \mu \mathrm{g} / \mathrm{mL}$, SMA (Sigma-Aldrich) 0.4$1.2 \mu \mathrm{g} / \mathrm{mL}$. The polymer-labelled system Bright vision poly HRP (Immunologic, Duiven, the Netherlands) was used as secondary antibody and incubated for
30 min. Visualisation was done with the peroxidase substrate NovaRED ${ }^{\mathrm{TM}}$ (Vector Laboratories) and counterstaining with haematoxylin. A special fixation protocol was further used to display the fat content in pure fat samples, microtissue-SVF and standard-SVF. After primary fixation with formalin and rinsing, the samples were fixed for $4 \mathrm{~h}$ with $2 \%$ osmium tetroxide $\left(\mathrm{OsO}_{4}\right)$ to preserve and visualise lipids. After subsequent rinsing, the samples were processed as the standard histological sections and stained with H\&E. Images were acquired with a light microscope (Nikon E800; Nikon).

\section{Immunofluorescence staining}

To visualise $\mathrm{CD} 34^{+} / \mathrm{CD} 0^{+}$cells as indicator for ASCs presence (De Francesco et al., 2009), pure fat and isolated microtissue-SVF were placed into a 12-well plate. Both were washed with PBS, then blocked at room temperature for $2 \mathrm{~h}$ with a solution containing PBS, $0.2 \%$ bovine serum albumin (BSA; BD Biosciences) and $0.1 \%$ gelatine from cold-waterfish skin (Sigma-Aldrich). The same solution was used during the incubation with the antibody and for the washing steps, if not indicated differently. The primary antibodies CD34 and CD90 (both $1 \mu \mathrm{g}$ ) $\mathrm{mL}$; Novus/Bio-Techne Ltd., Abingdon, UK) were applied overnight at $4{ }^{\circ} \mathrm{C}$. On the next day, both conditions were washed and incubated for $4 \mathrm{~h}$ at room temperature in the dark with the secondary antibodies goat anti-mouse Rhodamine $\operatorname{Red}^{\mathrm{TM}}-\mathrm{X}$ and donkey anti-rabbit Alexa Fluor 488 (both $1 \mu \mathrm{g} / \mathrm{mL}$; Invitrogen). Nuclear counterstaining was performed with DAPI (0.38 ng/mL; Invitrogen) at room temperature for $10 \mathrm{~min}$ in the dark. The samples were washed with PBS and mounted on microscope slides using the Prolong Antifade kit (Molecular Probes). Images were acquired using a confocal microscope (Nikon C2, Nikon).

\section{Enzyme-linked immunosorbent assay (ELISA)}

To analyse the secretion of human indoleamine 2,3-dioxygenase (IDO) and prostaglandin E2 (PGE2), the supernatant of freshly isolated standard-SVF and microtissue-SVF was cultivated for $24 \mathrm{~h}$ in sterile-filtered Dulbecco's modified Eagle's medium (DMEM)-low glucose (Lonza) containing 10 \% FCS and $2 \mathrm{mM}$ L-glutamine (PAA Laboratories $\mathrm{GmbH}$ ). The supernatant was collected and stored at $-80^{\circ} \mathrm{C}$ until analysis. An IDO DuoSet ELISA Development System kit (R\&D Systems) and a Prostaglandin E2 ELISA Kit (Abcam) were used according to the manufacturer's instructions. Absorbance was measured using an Infinite ${ }^{\circledR}$ M200 Multimode Microplate Reader (Tecan) and correlated to a standard curve.

\section{Trophic factor release}

For trophic factor release analysis of freshly isolated standard-SVF and microtissue-SVF, $5 \times 10^{5}$ cells were seeded in a T-25 flask in $2.5 \mathrm{~mL}$ EGM- 2 medium. Cells were allowed to adhere for $2 \mathrm{~h}$ and, subsequently, 
Table 2a. List of antibodies against which antigens were obtained. Freshly isolated SVF after standard-SVF or microtissue-SVF isolation were characterised using antibodies against these antigens. Details of suppliers are included. $\alpha$-SMA: alpha-smooth muscle actin; APC: allophycocyanin; CD: cluster of differentiation; PerCP: peridinin chlorophyll protein complex; FITC: fluorescein-isothiocyanate; PE: phycoerythrin; LYVE-1: lymphatic vessel endothelial receptor 1; SSEA3: stage-specific embryonic antigen 3.

\begin{tabular}{|c|c|}
\hline Antibody against & Supplier \\
\hline$\alpha$-SMA-APC & R\&D, Wiesbaden-Nordenstadt, Germany \\
\hline CD1c-PerCP & BioLegend, San Diego, CA, USA \\
\hline CD13-FITC & eBioscience, Vienna, Austria \\
\hline CD14-FITC & BD Biosciences, Schwechat, Austria \\
\hline CD29-PerCP & ProtTech, Phoenixville, PA, USA \\
\hline CD31-FITC & BD Biosciences, Schwechat, Austria \\
\hline CD33-PE & eBioscience, Vienna, Austria \\
\hline CD34-APC & BD Biosciences, Schwechat, Austria \\
\hline CD44-APC & BioLegend, San Diego, CA, USA \\
\hline CD45-PerCP & BioLegend, San Diego, CA, USA \\
\hline CD45-V500 Horizon & BD Biosciences, Schwechat, Austria \\
\hline CD49d-PE & BD Biosciences, Schwechat, Austria \\
\hline CD68-APC & BioLegend, San Diego, CA, USA \\
\hline CD73-FITC & BD Biosciences, Schwechat, Austria \\
\hline CD90-PE & eBioscience, Vienna, Austria \\
\hline CD105-APC & BD Biosciences, Schwechat, Austria \\
\hline CD117-APC & eBioscience, Vienna, Austria \\
\hline CD133-PE & Milteny Biotec, Bergisch Gladbach, Germany \\
\hline CD146-PerCP & R\&D, Wiesbaden-Nordenstadt, Germany \\
\hline CD235a-FITC & eBioscience, Vienna, Austria \\
\hline CD326-PE & eBioscience, Vienna, Austria \\
\hline CD309-APC & Milteny Biotec, Bergisch Gladbach, Germany \\
\hline LYVE-1-APC & R\&D, Wiesbaden-Nordenstadt, Germany \\
\hline Podoplanin-PE & BioLegend, San Diego, CA, USA \\
\hline SSEA3-FITC & BD Biosciences, Schwechat, Austria \\
\hline Stro-1-PerCP & Novus/Bio-Techne Ltd., Abingdon, UK \\
\hline
\end{tabular}

Table $\mathbf{2 b}$. Combinations of antibodies used. Specific subpopulations were analysed through the following combination of the antibodies against CD31, CD34, CD45, CD90, CD146, SSEA3, CD105, LYVE-1 and podoplanin.

\begin{tabular}{|c|c|}
\hline Cell subpopulation & Antibody combination \\
\hline Endothelial progenitor cells (EPCs) & $\mathrm{CD}^{2} 5^{-} / \mathrm{CD} 31^{+} / \mathrm{CD} 34^{+}$ \\
\hline Pericyte-like cells & $\mathrm{CD}^{2} 5^{-} / \mathrm{CD} 31^{-} / \mathrm{CD} 146^{+}$ \\
\hline Supra-adventitial ASCs (SA-ASCs) & $\mathrm{CD}^{2} 5^{-} / \mathrm{CD} 31^{-} / \mathrm{CD} 146^{-} / \mathrm{CD} 34^{+}$ \\
\hline A mesenchymal subset & $\mathrm{CD}^{2} 4^{+} / \mathrm{CD} 90^{+\mathrm{A}}$ \\
\hline A pericytic subset & $\mathrm{CD} 90^{+} / \mathrm{CD} 146^{+}$ \\
\hline Lymphatic endothelial cells (LECs) & LYVE-1+/podoplanin $^{+}$ \\
\hline Multilineage differentiating stress enduring (Muse) cells & $\mathrm{SSEA3}^{+} / \mathrm{CD}^{2} 105^{+}$ \\
\hline
\end{tabular}


EGM-2 media was changed to serum-free media (DMEM-low glucose with $2 \mathrm{mM}$ L-glutamine). To include also non-adherent suspension cells, cells were collected, centrifuged and returned to the flask. $24 \mathrm{~h}$ after seeding, the supernatant was collected and stored at $-80^{\circ} \mathrm{C}$ until analysis. A customised array (RayBio, Norcross, GA, USA) was used for the trophic factor release analysis and performed according to the manufacturer's instructions. Signals were detected by enhanced chemiluminescence and recorded on an X-ray film. Signals were densitometrically quantified using ImageJ (NIH).

\section{Vascularisation induction and detection}

For determination of the vascularisation potential of standard-SVF and microtissue-SVF, a fibrin clot culture was performed (Holnthoner et al., 2015). $4 \times 10^{5}$ SVF cells after standard-SVF and microtissueSVF isolation were mixed with fibrinogen $(2.5 \mathrm{mg} /$ $\mathrm{mL}$; Baxter) and thrombin $(0.2 \mathrm{U} / \mathrm{mL}$; Baxter $)$ for clot formation and pipetted on coverslips in 12-well plates. Clots were polymerised at $37^{\circ} \mathrm{C}$ for $30 \mathrm{~min}$ and cultured for 2 weeks in EGM-2 containing aprotinin (100 KIU/mL; Baxter). Medium was changed every 3-4 d. After cultivation, clots were fixed with $4 \%$ paraformaldehyde (PFA), washed with PBS and incubated for $12 \mathrm{~h}$ in the dark with a FITC-conjugated monoclonal mouse anti-human CD31 antibody (1 : 50 dilution in PBS/1 \% BSA). Clots were again washed with PBS, then nuclear counterstaining was performed with DAPI $(0.38 \mathrm{ng} / \mathrm{mL}$ in PBS $/ 1 \%$ BSA) for $10 \mathrm{~min}$ at room temperature in the dark. For images in higher magnification, clots were incubated for $12 \mathrm{~h}$ in the dark with an Alexa-Fluor ${ }^{\circledR}$ 647-conjugated monoclonal mouse anti-human CD31 antibody (BD Biosciences; 1 : 100 dilution in PBS/1 \% BSA). Images were acquired using a fluorescence microscope (Axiovert 200 or Observer Z.1 for higher magnification). Number of vascular tubes per picture was counted.

\section{In vivo experiments}

An animal experiment permit was issued by the municipal government of Vienna and all experimental methods were consistent with the Guide for the Care and Use of Laboratory Animals of the US National Research Council (2011). For analysis of graft integration, pure fat and fat enriched with microtissue-SVF $\left(2.5 \times 10^{5}\right.$ cells $/ 50 \mu \mathrm{L}$ fat $)$ in a $9: 1$ ratio were injected intramuscularly into nude mice. A total of 16 NMRI nude mice (Charles River) weighting 22-27 g underwent surgery. After induction of anaesthesia by isoflurane (AbbVie), $50 \mu \mathrm{L}$ test samples were injected transcutaneously into the musculus quadriceps femoris hindlimbs in a randomised fashion. Either microtissue-SVF or a combination of fat and microtissue-SVF were applied in 6 replicates, while the remaining untreated hindlimbs served as an empty control. The implants were well tolerated and no adverse effects were observed. Analgesia was provided orally by $1 \mathrm{mg} / \mathrm{kg}$ meloxicam (Boehringer Ingelheim) prior to surgery and for up to $3 \mathrm{~d}$ post-surgery. After $28 \mathrm{~d}$, the animals were euthanised through cervical dislocation under isoflurane inhalation anaesthesia and samples were harvested by resecting the implantation region with the skin and subcutaneous tissue. The samples were fixated and histologically processed as described above in the histological staining section.

\section{Adipogenic differentiation and detection}

For adipogenic differentiation, cells derived from microtissue-SVF after 1 week in culture were seeded at a density of $7.4 \times 10^{3} / \mathrm{cm}^{2}$ in EGM-2 and incubated overnight. On the next day, medium was changed to adipogenic differentiation medium (DMEM)high glucose (Lonza) containing $10 \%$ FCS, 2 mM L-glutamine, $100 \mathrm{U} / \mathrm{mL}$ penicillin/streptomycin (P/S; Lonza), $1 \mu \mathrm{M}$ dexamethasone (Sigma-Aldrich), 0.5 mM 3-isobutyl-1-methylxanthine (IBMX; SigmaAldrich), $10 \mu \mathrm{g} / \mathrm{mL}$ insulin (Sigma-Aldrich) and $100 \mu \mathrm{M}$ indomethacin (Sigma-Aldrich) or control medium consisting of DMEM : F12/L-glutamine (Lonza) with $10 \%$ FCS and $100 \mathrm{U} / \mathrm{mL}$ P/S. Medium was changed every 3-4 d. After 1, 2, 3 and $7 \mathrm{~d}$, adipogenic differentiation was analysed with oil red O staining and quantification through RT-PCR of the specific markers, peroxisome proliferator-activated receptor gamma (PPAR $\gamma)$, fatty acid-binding protein 4 (FABP4) and leptin (LEP). For oil red O staining of lipid droplets, cells were fixed for $1 \mathrm{~h}$ with $4 \%$ formaldehyde. After washing with Aqua Dest, the cells were rinsed with $70 \%$ ethanol for $2 \mathrm{~min}$ and stained for 5-15 min with oil red O solution (SigmaAldrich). Then, the cells were washed with Aqua Dest, counterstained for 1-3 min with haematoxylin solution and washed with tap water. Images were acquired using a light microscope (Axiovert 200).

\section{Osteogenic differentiation and detection}

For osteogenic differentiation, cells derived from microtissue-SVF after 1 week in culture were seeded at a density of $1.1 \times 10^{3} / \mathrm{cm}^{2}$ in EGM-2 and incubated overnight. On the next day, medium was changed to osteogenic differentiation medium DMEM-low glucose containing $10 \%$ FCS, 2 mM L-glutamine, $100 \mathrm{U} / \mathrm{mL} \mathrm{P} / \mathrm{S}, 10 \mathrm{nM}$ dexamethasone, $150 \mu \mathrm{M}$ ascorbat-2-phosphate (Sigma-Aldrich), $10 \mathrm{mM} \beta$-glycerophosphate (StemCell Technologies, Cologne, Germany) and $10 \mathrm{nM}$ dihydroxy-vitamin D3 (Sigma-Aldrich) or control medium consisting of DMEM : F12/L-glutamine with $10 \%$ FCS and $100 \mathrm{U} /$ $\mathrm{mL}$ P/S. Medium was changed every 3-4 d. After $21 \mathrm{~d}$, osteogenic differentiation was analysed with alizarin red staining and quantification through RT-PCR of the specific markers alkaline phosphatase (ALPL), osteocalcin (BGLAP) and osteopontin (SPP1). For alizarin red staining of calcified structures, cells were fixed for $1 \mathrm{~h}$ with $70 \%$ ethanol at $-20^{\circ} \mathrm{C}$ and stained with alizarin red solution (Merck) for $15 \mathrm{~min}$. Images were acquired using a light microscope (Axiovert 200). 


\section{Chondrogenic differentiation and detection}

For chondrogenic differentiation in 3D micromass pellet cultures, $3 \times 10^{5}$ cells derived from microtissueSVF after 1 week in culture were centrifuged in chondrogenic differentiation medium [hMSC Chondro BulletKit (Lonza), 10 ng/mL BMP-6 (R\&D) and $10 \mathrm{ng} / \mathrm{mL}$ TGF-\$3 (Lonza)] in screw-cap micro tubes. The tubes were placed in an incubator at $37^{\circ} \mathrm{C}$, $5 \% \mathrm{CO}_{2}$ and $95 \%$ humidity with slightly open cap to allow for gas exchange. After $2 \mathrm{~d}$, the pellets were transferred to 96-well U-bottom plates (Greiner) with fresh medium. Medium was changed every 2-3 d. After $35 \mathrm{~d}$ of differentiation, chondrogenic differentiation was analysed with alcian blue and collagen type II staining as well as quantification through RT-PCR for the specific markers collagen type II alpha 1 (COL2A1) and aggrecan (AGC1) versus collagen type I alpha 1 (COL1A1) and versican (CSPG2). Histological samples were processed as described above in the histological staining section.

\section{Quantitative RT-PCR}

Samples for qRT-PCR were collected at distinct time points as indicated in the differentiation paragraphs and lysed or homogenised in TriReagent (SigmaAldrich). Extraction was facilitated by repeated pipetting of the cells or pellets. For total RNA isolation, the samples were centrifuged for $10 \mathrm{~min}$ at $4{ }^{\circ} \mathrm{C}$ and the supernatant was transferred into a fresh tube. For phase separation, $0.1 \mathrm{~mL}$ of 1-bromo3-chloropropane (BCP; Sigma-Aldrich) was added and samples shaken vigorously, incubated for $10 \mathrm{~min}$ and centrifuged for $10 \mathrm{~min}$ at $4{ }^{\circ} \mathrm{C}$. The aqueous phase was transferred into a fresh tube and precipitated with isopropanol for $30 \mathrm{~min}$ at $-20^{\circ} \mathrm{C}$. After centrifugation for $30 \mathrm{~min}$ at $4{ }^{\circ} \mathrm{C}$, the RNA pellet was washed with $75 \%$ ethanol, vortexed and centrifuged for $5 \mathrm{~min}$ at $4{ }^{\circ} \mathrm{C}$. Finally, RNA pellets were air-dried before dissolving them in nuclease-free water (Promega). Samples were stored at $-80{ }^{\circ} \mathrm{C}$ until use. RNA content and integrity were assessed using an Agilent 2100 Bioanalyzer with the RNA 6000 Nano Chips Kit (no. 5065-4476, Agilent Technologies). Isolated RNA was retrotranscribed to cDNA according to the High Capacity cDNA Archive Kit protocol (Applied Biosystems). Quantification of specific cDNAs was conducted in triplicate, using a LightCycler W 480 (Roche) and TaqMan ${ }^{\mathrm{TM}}$ gene expression assay (Applied Biosystems) for PPAR $\gamma$ (Hs00234592_m1), FABP4 (Hs00609791_m1), LEP (Cf02692890_m1), ALPL (Hs00758162_m1), BGLAP (Hs01587813_g1), SPP1 (Hs00167093_m1), CSPG2 (Hs00171642_m1), COL1A1 (Hs00164004_m1), COL2A1 (Hs00264051_ $\mathrm{m} 1$ ) and AGC1 (Hs0015936_m1). The PCR was programmed as follows: initial denaturation at $95^{\circ} \mathrm{C}$ for $10 \mathrm{~min}$, followed by $95^{\circ} \mathrm{C}$ for $10 \mathrm{~s}, 60^{\circ} \mathrm{C}$ for $45 \mathrm{~s}$, cycled 50 times. Cooling to $40^{\circ} \mathrm{C}$ was held for $30 \mathrm{~s}$. Slope speed was $20^{\circ} \mathrm{C} / \mathrm{s}$. Standard curves were prepared for quantification and expression values were normalised to the housekeeping gene, hypoxanthine-guanine phosphoribosyl transferase
(HPRT). The efficiency-corrected quantification was performed automatically, using the LightCycler 480 Relative Quantification Software (Roche).

\section{Statistical analysis}

Data are presented as mean \pm standard deviation (SD). Statistical analysis was performed using PRISM6 (GraphPad), parametric two-tailed $t$-test or two-way ANOVA Tukey's post-hoc for trophic factor release analysis. $p<0.05$ was considered statistically significant.

\section{Results}

The optimised standard-SVF isolation protocol with low collagenase concentration was adapted resulting in SVF cells being protected within their natural environment, hence providing a microtissue devoid of fat components and highly enriched in SVF cells.

\section{Microtissue-SVF isolation increased cell yield and viability}

The macroscopic and microscopic appearance of the microtissue-SVF was characterised by a heterogeneous and partially fibrous matrix with individually distributed cells and cell aggregates. In contrast, pure fat contained few individual cells and was dominated by lipid droplets, while the standard-SVF consisted of single cells and small cell aggregates (Fig. 1a; phase contrast, live/dead staining, $\mathrm{OsO}_{4}$ fixation). Staining of live (calcein AM) versus dead (EthD-1) cells revealed a small and moderate number of dead cells in pure fat and standard-SVF, respectively, but almost none in the microtissue-SVF. The appearance of the native fat tissue was dominated by living cells with adipocyte morphology. In the microtissue-SVF, the living cells mainly resided within the ECM areas, which suggested a protective role of the microtissue. Automated quantification of the viable versus dead cells in microtissue-SVF versus standard-SVF isolation supported the morphological data. Microtissue-SVF had a $10 \%$ increased viability as compared to standard-SVF isolation (Fig. 1b). Not only the viability was increased in the microtissue-SVF but also the total cell yield, which was significantly higher (1.8-fold) as compared to standard-SVF isolation (Fig. 1b). ATP concentration as an indicator for cellular fitness and energy production was at similarly high levels in both SVF isolates.

\section{The microtissue-SVF maintained the heterogeneous SVF character}

According to the guidelines of the International Federation for Adipose Therapeutics and Science (IFATS) and the International Society for Cellular Therapy (ISCT) (Bourin et al., 2013), the isolated standard-SVF and microtissue-SVF were characterised for the distinct surface marker profile by flow cytometric analysis. The percentage of cells positive for the mesenchymal markers CD73 (> 45\%) and CD90 

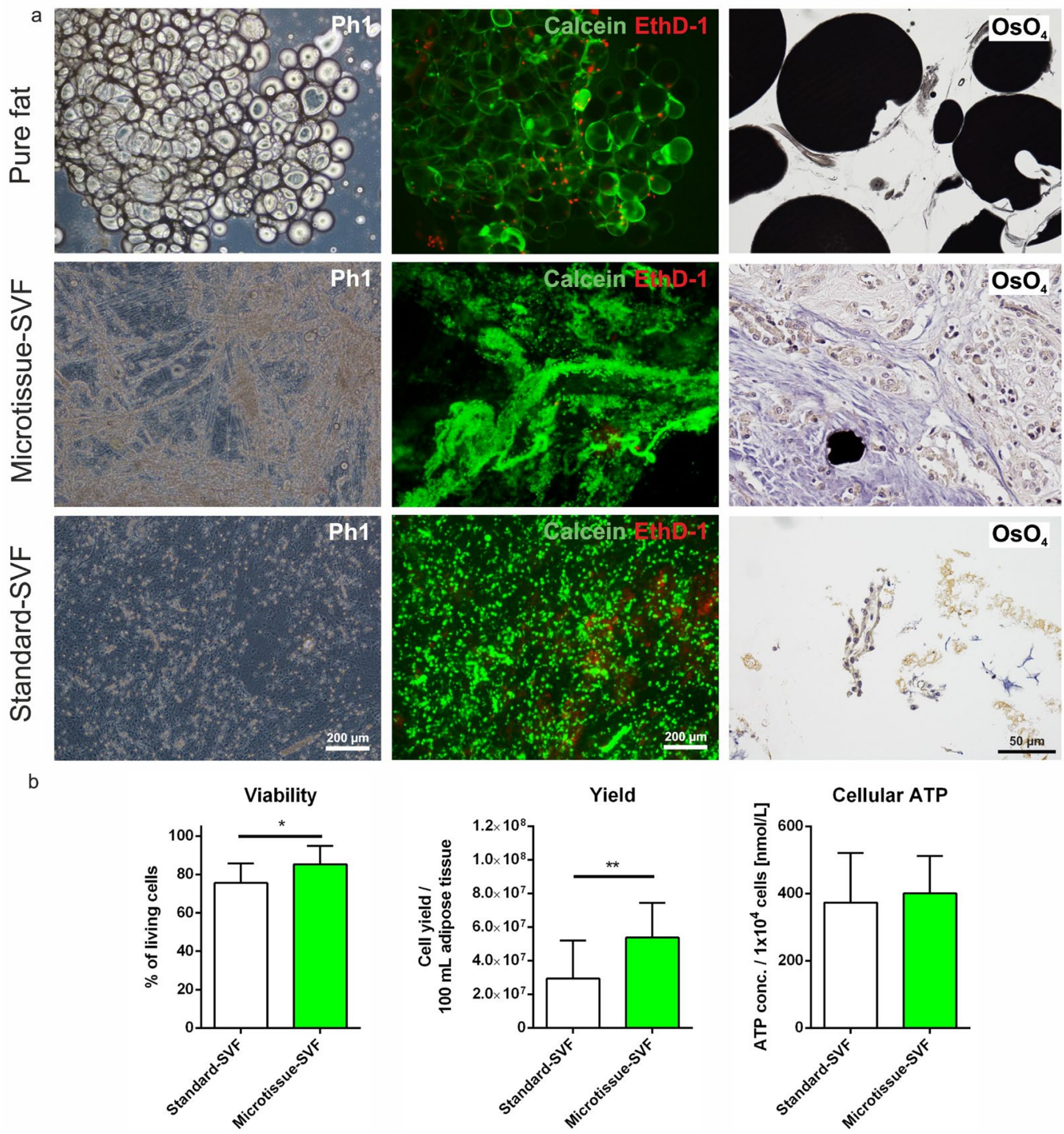

Fig. 1. Morphology and vitality of pure fat, microtissue-SVF and standard-SVF. (a) Structure and vitality of fresh pure fat (liposuction material), microtissue-SVF and standard-SVF. Phase contrast images reveal that pure fat mainly contained lipid droplets, while the microtissue-SVF had a fibrous appearance and the standard-SVF was mainly cellular. Live/dead staining showed mainly vital cells (green) in all three groups,

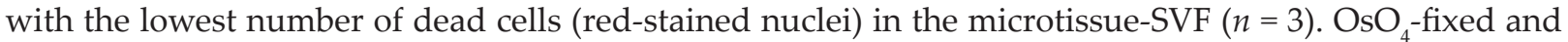
sectioned samples displaying lipid droplets in black revealed that, in contrary to the large droplets in pure fat, the microtissue-SVF contained only individual small droplets enclosed inside the matrix. The standardSVF showed no signs of residual lipid material. Representative images showing different locations of each sample (Ph1, calcein, EthD-1 and $\mathrm{OsO}_{4}$ ). Scale bars $=200 \mu \mathrm{m}$ and $50 \mu \mathrm{m}$. (b) Viability, cell yield and ATP concentration of the microtissue-SVF ( $n=8$ for viability and cell yield; $n=4$ for ATP) versus standard-SVF ( $n=15$ for viability and cell yield; $n=13$ for ATP) showed a higher viability and larger cell percentage in the microtissue-SVF, but a similar cellular ATP level. Data are presented as mean \pm SD. ${ }^{*} p<0.05 ;{ }^{* *} p<0.01$.

(>65\%), the progenitor marker CD34 ( $\geq 60 \%)$ and the haematopoietic marker CD45 (<35\%) complied with the guidelines of the IFATS and ISCT. The percentage of cells positive for the vascular marker CD31 was approximately $45 \%$ and $55 \%$, larger as compared to $<20 \%$ defined by Bourin et al. (2013) (Table 3). Due to the heterogeneous character of the SVF, the isolated standard-SVF and microtissue-SVF were further screened for a panel of various immunophenotypic markers and markers represented on MSCs, preadipocytes, fibroblasts, vascular smooth muscle cells, endothelial cells, endothelial progenitor cells, pericyte-like cells, macrophages, lymphocytes and lymphatic endothelial cells were identified, among others (Table 3). The percentages of all tested markers were enhanced in the microtissue-SVF as compared to the standard-SVF (apart from CD33, CD146), but only $\alpha$-SMA reached significance. Additionally to these, specific subpopulations of a mesenchymal subset $\left(\mathrm{CD} 34^{+} / \mathrm{CD}^{\circ} 0^{+}\right)$, a pericytic subset $\left(\mathrm{CD}^{+} / \mathrm{CD}^{+} 46^{+}\right)$, LECs (podoplanin ${ }^{+} /$LYVE-1) and Muse cells (SSEA3 ${ }^{+}$/ $\mathrm{CD} 105^{+}$) were identified in the isolated standard-SVF and microtissue-SVF in similar percentages (Table 4). 
Table 3. Identification and quantification of surface marker in standard-SVF and microtissue-SVF with flow cytometry analysis. The standard-SVF and microtissue-SVF revealed all SVF-specific immunophenotype marker analysed by flow cytometry according to the guidelines of the IFATS and ISCT. Additionally, further marker for distinct stem and progenitor cell types could be detected ( $n=4$ for microtissue-SVF and $n=3$ for standard-SVF). Data are presented as mean \pm SD.

\begin{tabular}{|c|c|c|c|}
\hline \multirow{2}{*}{\multicolumn{2}{|c|}{ Marker }} & \multicolumn{2}{|c|}{ Positive cells ( $\%)$} \\
\hline & & Standard-SVF & Microtissue-SVF \\
\hline CD29 & Mesenchymal stromal & $76 \pm 25$ & $89 \pm 3$ \\
\hline CD90 & Mesenchymal stromal & $68 \pm 20$ & $76 \pm 6$ \\
\hline CD44 & Mesenchymal stromal & $60 \pm 19$ & $68 \pm 8$ \\
\hline CD34 & Progenitor & $60 \pm 15$ & $67 \pm 6$ \\
\hline CD73 & Mesenchymal stromal & $48 \pm 22$ & $59 \pm 7$ \\
\hline$\alpha-S M A$ & Vascular smooth muscle & $30 \pm 9$ & $58 \pm 25$ \\
\hline CD31 & Endothelial & $45 \pm 11$ & $55 \pm 6$ \\
\hline CD13 & Monocyte, granulocyte, fibroblast & $33 \pm 14$ & $48 \pm 11$ \\
\hline CD146 & Pericyte-like, endothelial & $34 \pm 11$ & $34 \pm 4$ \\
\hline Podoplanin & Lymphatic endothelial & $25 \pm 11$ & $33 \pm 11$ \\
\hline CD45 & Haematopoietic & $23 \pm 7$ & $31 \pm 10$ \\
\hline CD68 & Monocyte, macrophage & $8 \pm 3$ & $31 \pm 6$ \\
\hline CD235a & Erythrocyte & $23 \pm 22$ & $29 \pm 23$ \\
\hline CD49d & Lymphocyte & $7 \pm 1$ & $26 \pm 17$ \\
\hline CD117 & Haematopoetic & $14 \pm 7$ & $25 \pm 8$ \\
\hline LYVE-1 & Lymphatic endothelial & $18 \pm 6$ & $24 \pm 6$ \\
\hline CD14 & Macrophage, monocyte, lymphocyte, haematopoietic & $7 \pm 3$ & $16 \pm 5$ \\
\hline CD133 & Endothelial progenitor & $5 \pm 2$ & $15 \pm 7$ \\
\hline SSEA3 & Embryonic stem cell, Muse cell & $12 \pm 8$ & $14 \pm 6$ \\
\hline CD105 & Mesenchymal stromal & $12 \pm 4$ & $14 \pm 3$ \\
\hline CD326 & Epithelial & $7 \pm 3$ & $12 \pm 6$ \\
\hline CD33 & Leukocyte, natural killer, T-cell & $12 \pm 7$ & $9 \pm 2$ \\
\hline CD309 & Vascular endothelial & $5 \pm 2$ & $8 \pm 4$ \\
\hline Stro-1 & Mesenchymal stromal & $6 \pm 1$ & $8 \pm 5$ \\
\hline
\end{tabular}

\section{Microtissue-SVF structure}

Comparison between microtissue-SVF, standardSVF and pure fat revealed that the most obvious feature of the microtissue-SVF was the large amount of ECM with a simultaneous lack of lipid, represented by few residual droplets only (Fig. 1). Also, macroscopically, the appearance of the microtissue-SVF was dominated by its matrix that gave the material a translucent to opaque mucous appearance containing fibrous elements (Fig. 2a). To characterise this matrix and its structural relation with the cells, detailed morphological analyses were performed. Matrix-specific histochemical and immunohistochemical stainings identified mucopolysaccharides (alcian blue) and collagen type I (antibody labelling) as the main ECM components (Fig. 2b,c). Mucopolysaccharides appeared as homogenous areas with few cells that were mainly individually distributed. Collagen type I formed fibrous strands within the mucous matrix or areas of fine fibrillary networks. The latter were co-localised with collagen type III and areas of high cellularity (Fig. 2d). Cells forming lumina and tube-like structures were identified as endothelial cells $\left(\mathrm{CD} 31^{+}\right)$, either appearing alone as capillaries or surrounded by pericytes $\left(\mathrm{SMA}^{+}\right)$(Fig. 2f). Within these vessel and cell aggregates, also fibroblasts (clone TE- $7^{+}$) were identified (Fig. 2e). The areas with high cellularity, rich in collagen matrix, and the areas with low cellularity, rich in mucopolysaccharides, had an extension of few hundreds $\mu \mathrm{m}$ and were spread-out evenly throughout the microtissue-SVF (Fig. 2b-f). 
Table 4. Double staining of distinct surface markers in standard-SVF and microtissue-SVF by flow cytometry analysis. Standard-SVF and microtissue-SVF revealed a mesenchymal subset $\left(\mathrm{CD} 34^{+} / \mathrm{CD}^{+} 0^{+}\right.$, a pericytic subset $\left(\mathrm{CD} 90^{+} / \mathrm{CD} 146^{+}\right)$, lymphatic endothelial cells (podoplanin $\left.{ }^{+} / \mathrm{LYVE}-1\right)$ and multilineage differentiating stress enduring cells (SSEA3 $\left.{ }^{+} / \mathrm{CD} 105^{+}\right)(n=4$ for microtissue-SVF and $n=3$ for standard-SVF). Data are presented as mean \pm SD.

\begin{tabular}{|c|c|c|c|}
\hline \multicolumn{2}{|c|}{ Marker } & \multicolumn{2}{|c|}{ Positive cells (\%) } \\
\hline & & Standard-SVF & Microtissue-SVF \\
\hline $\mathrm{CD} 34^{+} / \mathrm{CD} 90^{+}$ & Mesenchymal subset & $62 \pm 17$ & $67 \pm 4$ \\
\hline $\mathrm{CD} 0^{+} / \mathrm{CD} 146^{+}$ & Pericytic subset & $39 \pm 13$ & $36 \pm 6$ \\
\hline Podoplanin ${ }^{+} /$Lyve- $1^{+}$ & Lymphatic endothelial cell & $14 \pm 2$ & $17 \pm 7$ \\
\hline SSEA3 $^{+} / \mathrm{CD} 105^{+}$ & Muse cell & $7 \pm 3$ & $7 \pm 1$ \\
\hline
\end{tabular}

The microtissue-SVF provided regenerative cells Viable, regenerative cells are required for successful therapeutic applications (Dykstra et al., 2017). Pure fat and microtissue-SVF were stained for the mesenchymal marker CD90 and CD34, a marker associated with cells of a progenitor status (Sidney et al., 2014). In pure fat, there were elongated CD34+ cells and few $\mathrm{CD} 90^{+}$cells visible (Fig. 3). Some CD90 $/$ $\mathrm{CD}^{+} 4^{+}$cells were visible. In contrast, the isolated microtissue-SVF was rich in $\mathrm{CD} 90^{+}$and $\mathrm{CD} 34^{+}$cells and contained $\mathrm{CD} 90^{+} / \mathrm{CD} 34^{+}$cells, confirming the presence of regenerative cells within the microtissueSVF. These results confirmed that the isolated microtissue-SVF contained viable and regenerative cells, highly enriched in its ECM.

\section{Microtissue-SVF isolation increased the percentage} of specific subpopulations

As the cell yield was increased after microtissue-SVF isolation, whether this increase might correlate with the enrichment of specific subpopulations within the heterogeneous SVF was examined. Interestingly, EPCs (1.8-fold) and SA-ASCs (1.7-fold) were significantly increased by microtissue-SVF isolation as compared to standard-SVF isolation (Fig. 4). The relative number of pericyte-like cells was similar after standard-SVF and microtissue-SVF isolation.

\section{The microtissue-SVF showed enhanced release of PGE2}

As trophic factors are highly relevant for tissue repair (Fu et al., 2017), the secretion of pro-regenerative factors (e.g. angiogenic and immunomodulatory) was explored in supernatants conditioned for $24 \mathrm{~h}$ with freshly isolated standard-SVF and microtissue-SVF. Substantial levels of IDO and PGE2, two mediators of immunomodulation, were detected in both SVF variants. IDO concentration was increased in microtissue-SVF (2.4-fold) as compared to standardSVF supernatant, although not reaching significance (Fig. 5). However, there was a highly significant increase in PGE2 (15-fold) in microtissue-SVF as compared to standard-SVF supernatant. All analysed factors were expressed in the supernatant of both SVFs (Fig. 5) at similar protein levels in the standard-SVF and microtissue-SVF, as measured by a customised array microarray (RayBio). There was a slight but not significantly enhanced release of interleukin-8 (IL-8), monocyte chemoattractant protein-1 (MCP-1), tissue inhibitor of metalloproteinase (TIMP)-1, TIMP-2 and epidermal growth factor (EGF) after microtissue-SVF isolation.

\section{The microtissue-SVF displayed a high vascularisation potential}

Efficient vascularisation is a key element in regeneration and for successful graft integration and survival in tissue engineering (Eto et al., 2012). Therefore, standard-SVF and microtissue-SVF were characterised in 3D fibrin matrices for their potential to form tube-like structures, an in vitro indicator for angiogenesis (Rohringer et al., 2014). After 2 weeks, microtissue-SVF isolation showed a more pronounced vascular network formation of CD31 cells as compared to standard-SVF isolation (Fig. 6a). A higher magnification demonstrated a branching point in the microtissue-SVF. Quantitative analysis revealed a significantly larger number of tubes in the microtissue-SVF group (2.9-fold) (Fig. 6b), suggesting an improved vascularisation potential.

The microtissue-SVF was successfully integrated into the surrounding tissue after intramuscular injection

One typical clinical application is the use of SVF together with fat grafting material to prolong graft survival, improve vascularisation and integration of transplanted grafts in the surrounding tissue (Yoshimura et al., 2008). Therefore, pure fat and fat enriched with microtissue-SVF were injected intramuscularly into nude mice. Both grafts integrated after $14 \mathrm{~d}$, whereas microtissue-SVF cotransplantation resulted in high cellularity in the adipose tissue and a high degree of vascularisation (Fig. 7).

\section{The microtissue-SVF showed a trilineage differentiation potential}

The microtissue-SVF was analysed for its in vitro differentiation potential using standard differentiation cultures, analysed by quantitative RT-PCR and histological staining. Upon adipogenic 
induction, the adipogenic markers PPAR $\gamma, \mathrm{FABP} 4$ and LEP were significantly upregulated after only $1 \mathrm{~d}$ (Fig. 8a). The staining with oil red $\mathrm{O}$ demonstrated that lipid droplet formation started after only $2 \mathrm{~d}$ and was pronounced after $7 \mathrm{~d}$ of differentiation (Fig. $8 b)$. These results indicated the excellent adipogenic differentiation potential of the microtissue-SVF, as adipogenic differentiation is detected after 14-21 d of induction in previous studies (Priglinger et al., 2018; Priglinger et al., 2017). Upon osteogenic induction, expression of the specific osteogenic markers ALPL, BGLAP and SPP1 was increased after $21 \mathrm{~d}$, being significant for BGLAP and SPP1 (Fig. 8c). Mineral deposition staining with alizarin red at the same time point confirmed the osteogenic differentiation of the microtissue-SVF (Fig. 8d). Chondrogenic differentiation was analysed using 3D micromass pellet cultures. After $35 \mathrm{~d}$, the general expression of matrix proteins was significantly enhanced as compared to standard-SVF (COL1A1, COL2A1 and AGC1; Fig. 8e). The differentiation index of COL2A1/COL1A1 and AGC1/CSPG2 revealed a higher activation of cartilage specific components (Fig. 8f). Also, the histological analysis showed a strong staining with alcian blue and collagen type II, which demonstrated the potential for chondrogenic differentiation and cartilage-like tissue formation (Fig. 8g). These results confirmed the trilineage differentiation potential of the microtissue-SVF.
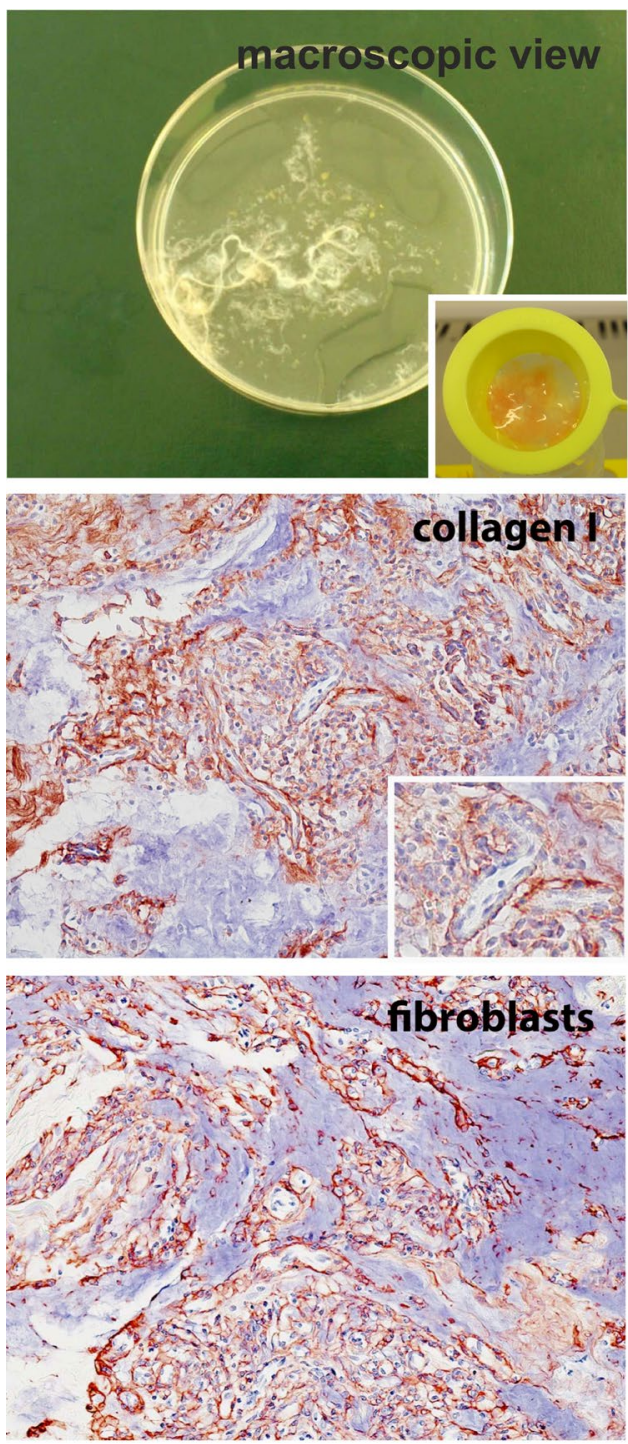
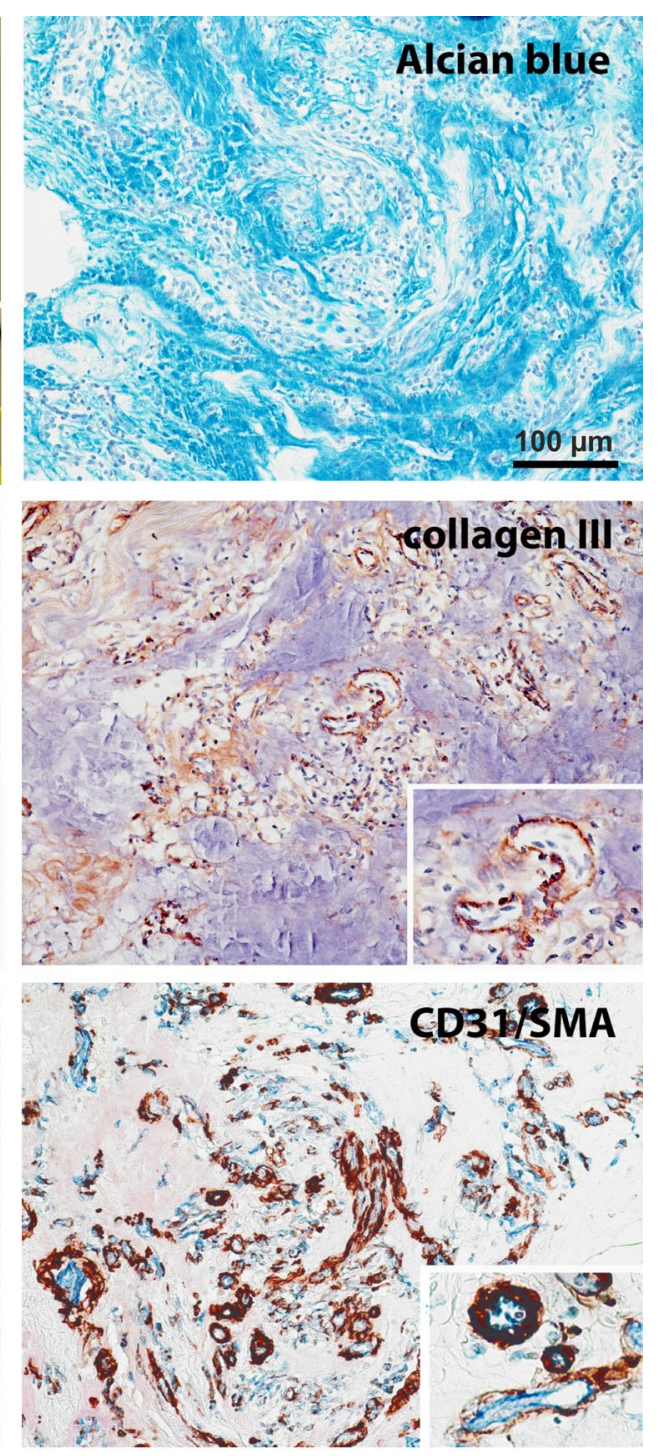

Fig. 2. Characterisation of the matrix and cellular components of the microtissue-SVF. (a) Macroscopically, the microtissue-SVF appeared as a translucent to opaque mucous material with fibrous elements. In histological sections, the matrix stained with (b) alcian blue for mucopolysaccharides in some regions, while other areas were positive for (c) collagen type I and (d) III, which were co-localised. Collagen-rich areas were highly cellular and vessels were discernible (inserts). (f) The inner wall of the vessels was positive for the endothelial marker CD31 and, in some cases, the surrounding cells were SMA+, indicating pericytes. Apart from vessels, also fibroblasts (e) were identified in the highly cellular, collagen-rich areas $(n=3)$. Representative images. Scale bar $=100 \mu \mathrm{m}$. 

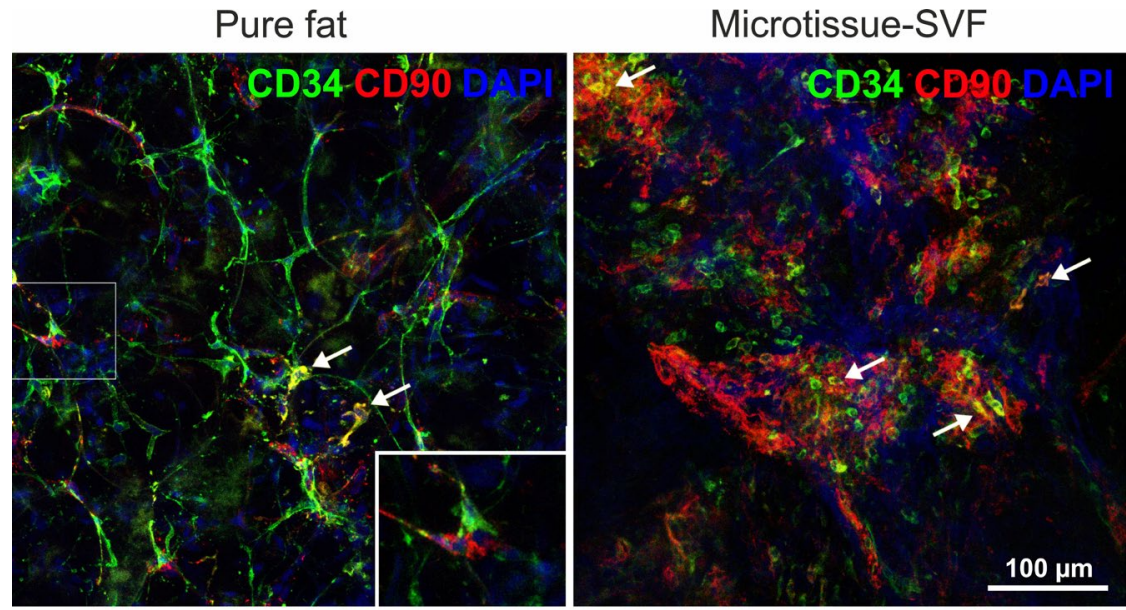

Fig. 3. Fluorescence microscopic images of pure fat and microtissue-SVF labelled against the marker for regenerative cells (CD34, CD90). In pure fat (left), CD34 ${ }^{+}$cells (green) located between the lipid droplets and few $\mathrm{CD}^{+}$cells (red) were visible (nuclei stained blue). The insert showed a higher magnification of a pair of $\mathrm{CD} 4^{+}$and $\mathrm{CD} 90^{+}$cells. Some cells were double stained and appeared in yellow (arrows). In the microtissue-SVF (right), cells were aggregated on/in the matrix. Apart from the green CD34 ${ }^{+}$cells, a large proportion of cells were CD90 (red) and some were double stained (arrow). Representative confocal images, overlay. Scale bar $=100 \mu \mathrm{m}$.

\section{Discussion}

The regenerative characteristics of an intraoperative GMP-compliant fat derivative with minimally manipulated cells termed microtissue-SVF was described. Until now, there were two ways for SVF isolation, diverse non-enzymatic methods using physical forces and enzymatic methods e.g. using collagenase, both followed by a cell selection step, mostly performed by centrifugation (Oberbauer et al., 2015). Mechanical emulsification alone leads to partial disruption of mature adipocytes and ECM components - generating homogenised adipose tissue fragments which are optimal for fat grafting - but does not generate single SVF cells (Oberbauer et al., 2015). Differently, the enzymatic dissociation of cell-cell and cell-tissue/matrix contacts provides a single-cell suspension defined by the IFATS and ISCT as SVF (Bourin et al., 2013).

Several isolation protocols aim to optimise and standardise the SVF isolation procedure (Aronowitz et al., 2018; Raposio et al., 2017). SVF cells dissociated from their natural microenvironment lack ECM protection from possible negative enzymatic impact (Busser et al, 2014; Seaman et al 2015). A rough enzymatic treatment, modifying substantially cell-matrix compounds, may affect the expression of surface antigens and immune cell function (Autengruber et al., 2012; Hagman et al., 2012). Substantial cell manipulation may impact cell therapeutic classification according to the local regulatory requirements. Since both, the current physical force and enzymatic isolation strategies, have drawbacks, there is a demand for an advanced SVF generation strategy. The described SVF-derivative delivered minimally manipulated therapeutic cells incorporated within their ECM, which served as a protective scaffold and provided the most natural environment for the cells. To demonstrate the highest possible cell quality for transplantation, the microtissue-SVF was analysed immediately after isolation. In comparison with the standard-SVF, which is a protocol already optimised by the authors with low enzyme concentration, the microtissue-SVF revealed a substantially higher cell yield, combined with high vitality and metabolic activity of the enriched cells. The percentage of dead cells was very low, suggesting that the procedure was well suited to actively remove adipocytes, while maintaining SVF cells highly viable.

Microtissue-SVF cells were supported by a gellike carrier (ECM residuals) and represented the

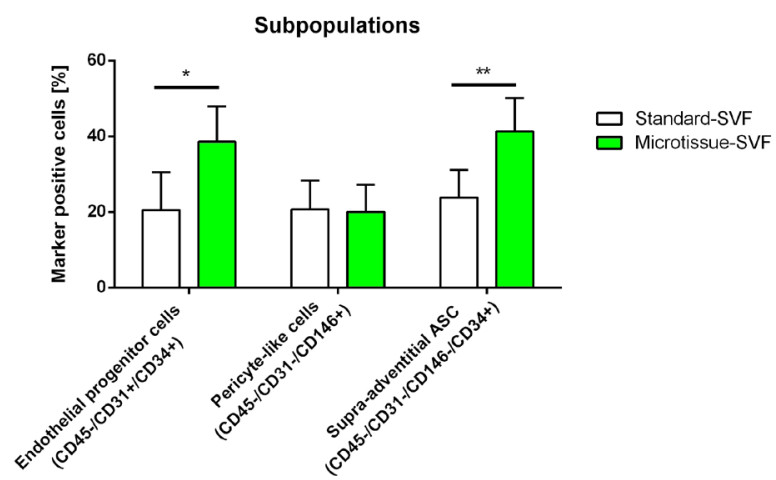

Fig. 4. Flow cytometry analysis of SVF subpopulations. In the microtissue-SVF, endothelial progenitor cells and supra-adventitial adiposederived stromal/stem cells were significantly enriched as compared to the standard-SVF. Pericyte-like cells had similar abundance in both types $(n=4)$. Data are presented as mean \pm SD; ${ }^{*} p<0.05 ;{ }^{* *} p<0.01$. 
stromal and the vascular fraction of the adipose tissue. It comprised fragmented connective tissue matrix and vascular structures composed of endothelial cells and pericytes and other regenerative cells, such as the ASCs. ECM components directly influence cell behaviour, including adhesion, spreading, proliferation and migration (Geutjes et al., 2010; Kim et al., 2012; Prockop, 2007; Wang et al., 2013a), suggesting a positive effect on the cells embedded in the microtissue-SVF. Qiu et al. (2018) employ decellularised fat tissue ECM as a scaffold for reseeding MSCs, resulting in improved regenerative efficacy in muscle tissue injury. Beside the typical IFATS-defined SVF-cell surface markers for mesenchymal, endothelial and haematopoietic cells (Bourin et al., 2013), the microtissue-SVF contained a broad range of cell types including pericytic, blood and lymphatic vascular and epithelial cells. Almost all markers tended to be enhanced in the microtissue-SVF as compared to the standardSVF. Considering the morphological appearance of the microtissue-SVF, the additional cells might derive from densely organised, collagen- and vesselrich areas of the derivative that were partially lost during the additional processing of the standardSVF isolation. Beside surface markers, a functional criterion to define the ASCs is their trilineage differentiation potential into the mesodermal lineages (Bourin et al., 2013). The microtissue-SVF revealed a high differentiation potential towards the adipo-, osteo- and chondrogenic lineage, which confirmed the large number of ASCs, as indicated by the phenotypic MSC marker profile. Especially, adipogenesis was surprisingly rapid and could be
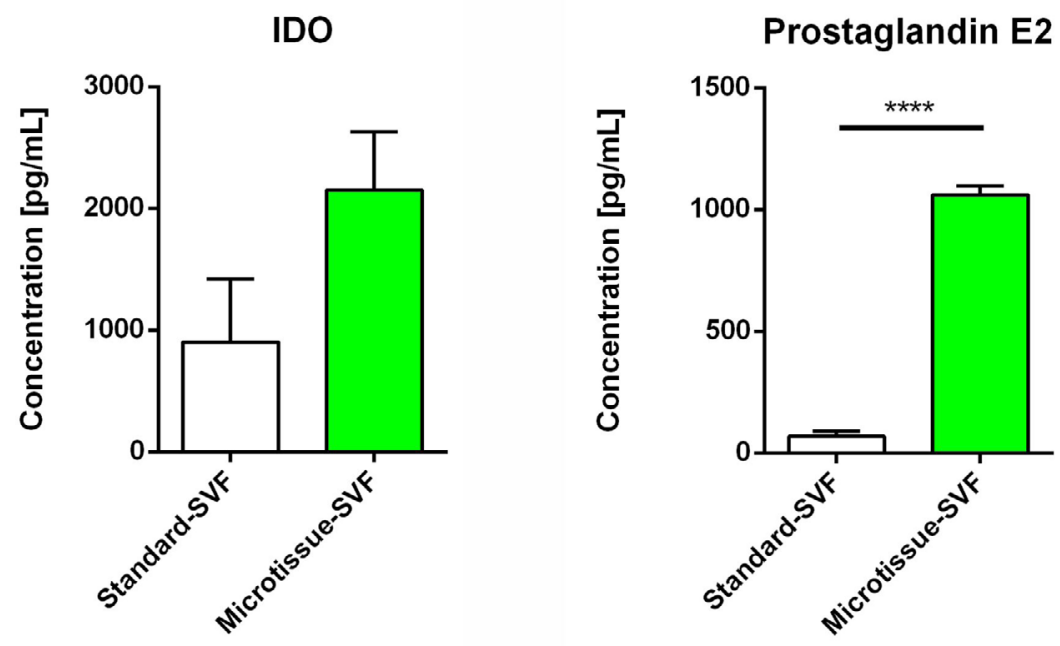

Trophic factor release

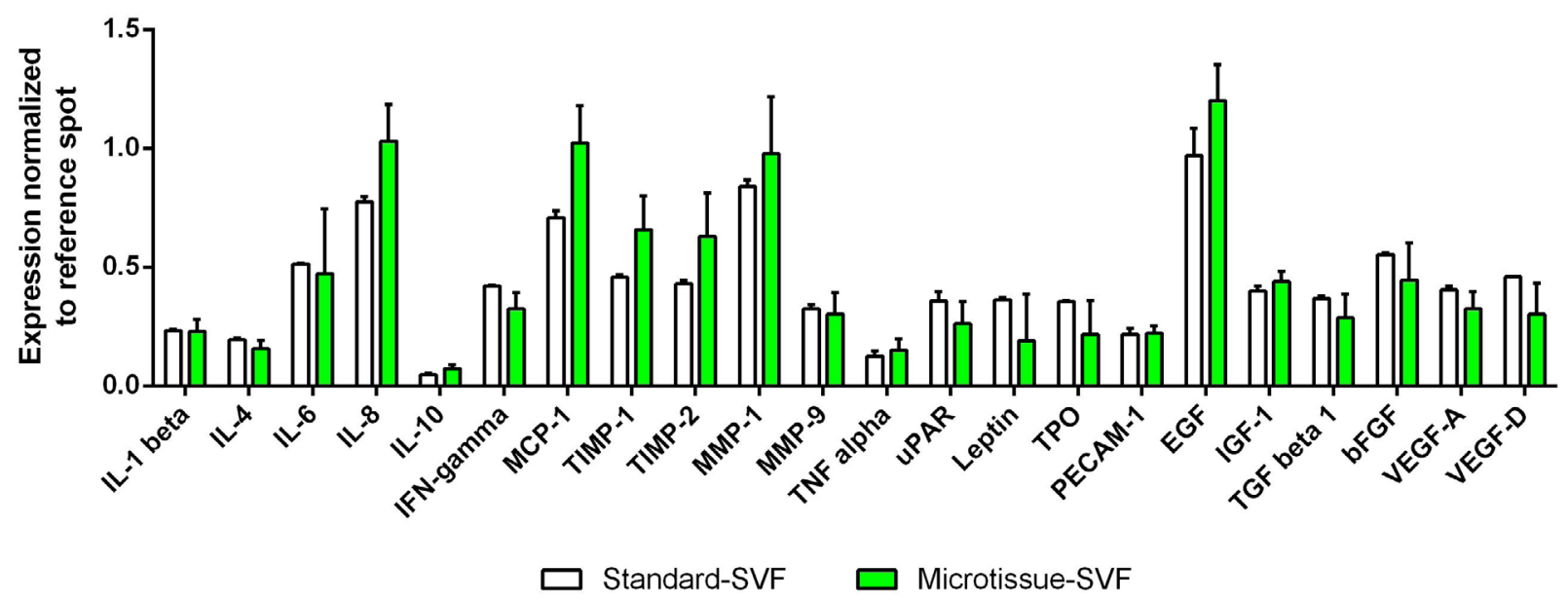

Fig. 5. Trophic factor release by the standard-SVF and microtissue-SVF. Both SVF types showed a typical immunomodulatory and pro-angiogenic protein profile. Notably, the microtissue-SVFs $(n=1-2$, 2-4 biological replicates) secreted more IDO as compared to the standard-SVFs $(n=1,2-4$ biological replicates) and significantly more PGE2, both anti-inflammatory factors. In general, inflammatory and anti-inflammatory factors of both SVF types showed a similar tendency, with individual marker slightly up or down regulated. Data are presented as mean $\pm \mathrm{SD}{ }^{* * * *} p<0.0001$. 
observed already after 2-3 d of differentiation by FABP4 and LEP RT-PCR.

For a potential cell therapeutic, it is important to deliver highly regenerative cell types (Corselli et al., 2013), which were found in the microtissue-SVF by subpopulation screening. Distinct regenerative SVF populations, such as Muse cells [a stress resistant stem cell population (Kuroda and Dezawa, 2014)], a pericytic subset CD90 $/$ CD146 ${ }^{+}$(Priglinger et al., 2017) and lymphatic endothelial cells, were present in the microtissue-SVF. Kuroda et al. (2010) show that Muse cells can be obtained as a minor subset from MSCs and are able to differentiate into ectodermal, endodermal and mesodermal lineage in vivo and have the capacity to replace damaged tissue, as demonstrated for liver regeneration (Katagiri et al., 2016). Other regenerative subpopulations identified in the microtissue-SVF were luminal EPCs $\left(\mathrm{CD} 45^{-} / \mathrm{CD} 31^{+} / \mathrm{CD} 34^{+}\right)$, SAASCs (CD45-/CD31 $\left.{ }^{-} / \mathrm{CD}^{-} 146^{-} / \mathrm{CD} 34^{+}\right)$and adventitial pericytes $\left(\mathrm{CD} 45^{-} / \mathrm{CD} 31^{-} / \mathrm{CD} 146^{+}\right)$, the two former of which were more abundant than in the standardSVF. Those three populations are located on the outer adventitial stromal ring in the SVF (Zimmerlin et al., 2010). Bianchi et al. (2013) obtain an increased number of pericytes and MSCs after mechanical cell isolation and enzymatic treatment as compared to lipoaspirate. A very abundant CD90+/CD34 ${ }^{+}$ mesenchymal subset (De Francesco et al., 2009) was detected in the microtissue-SVF, which was also apparent in the fluorescence staining. Zwierzina et al. (2015) define ASCs as DLK1 ${ }^{-} / \mathrm{cs}-\mathrm{CD} 34^{+} / \mathrm{CD}^{\circ} 0^{+} /$ $\mathrm{CD} 105^{+} \mathrm{dim} / \alpha-\mathrm{SMA}^{+} / \mathrm{CD} 45^{-} / \mathrm{CD} 31^{-}$cells with spindleshaped morphology and adipogenic potential, located on the adventitial stromal ring of vessels. In terms of regenerative action, CD34 is an important marker in SVF-derived cells (Guo et al., 2016). CD34 is expressed on various subpopulations of progenitor cells (Scherberich et al., 2013) and tissue-resident MSCs (Lin et al., 2012); however, its expression is lost during cell expansion (Mitchell et al., 2006). In the microtissue-SVF, flow cytometry double staining revealed that all CD $34^{+}$cells were also CD $90^{+}$, which was in accordance with a recent publication by Lutfi et al. (2018).

The MSC regenerative potential does not only derive from the cells with the potential to integrate and form new tissues but also from the factors they release to impact the local cells at the defect site (Kober et al., 2016; Salgado et al., 2010). These include immunomodulatory, angiogenic and antiapoptotic factors (Kapur and Katz, 2013). Both, the microtissue-SVF and standard-SVF showed a typical
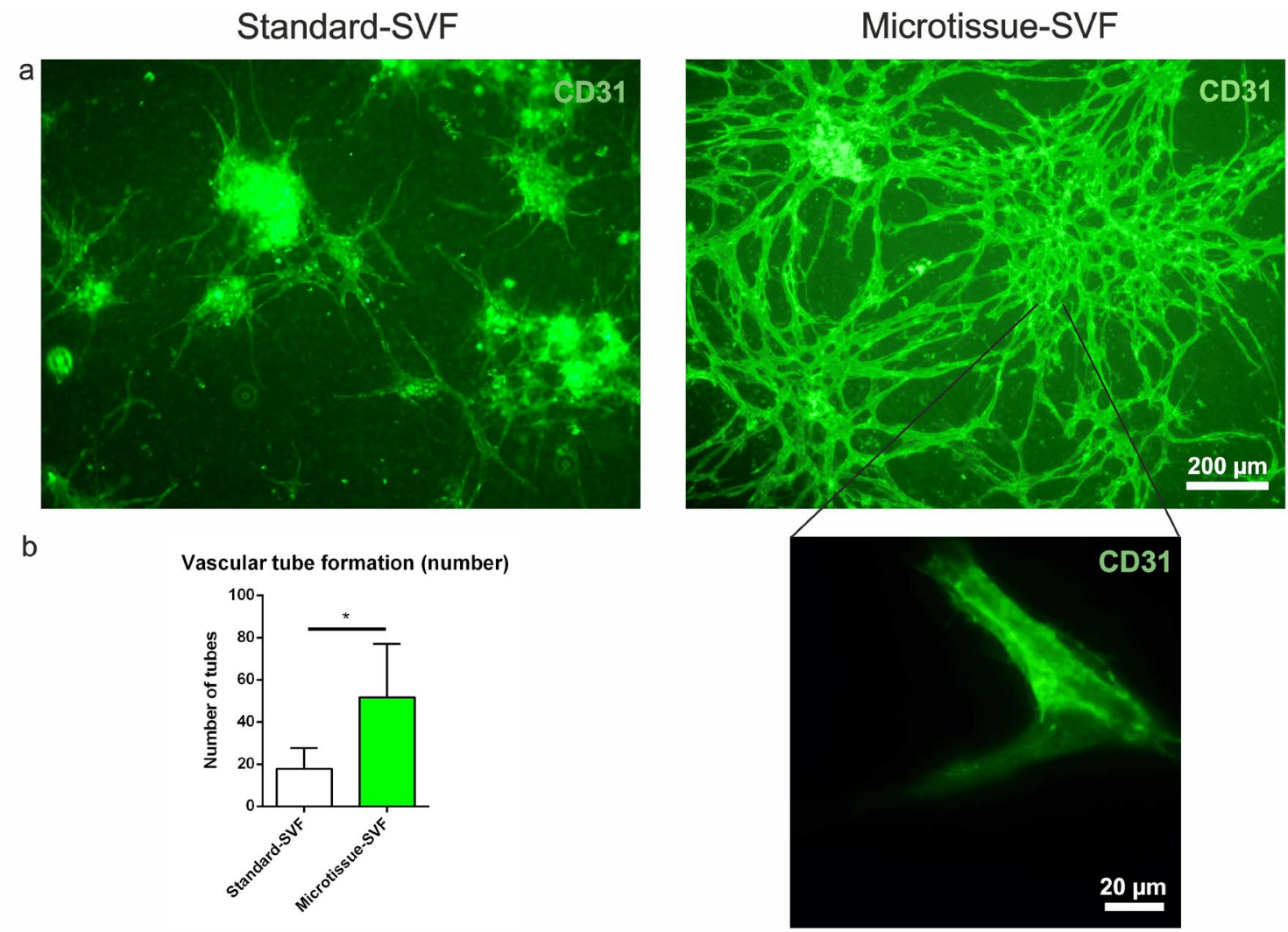

Fig. 6. Vascularisation potential of the microtissue-SVF in vitro. (a) The standard-SVF and microtissueSVF cultured in a 3D fibrin matrix and labelled with the endothelial marker CD31 showed more tube-like structures in the microtissue-SVF group. The higher magnification image showed the tube-like arrangement of two cells in more details. Representative images. Scale bar $=200 \mu \mathrm{m}$ and $20 \mu \mathrm{m}$. (b) Quantitative analysis of tube number confirmed the morphological impression with a significant increased number of tubes in the microtissue-SVF group ( $n=3 ; 5$ biological replicates) as compared to the standard-SVF group $(n=4 ; 6$ biological replicates). Data are presented as mean $\pm \mathrm{SD} ;{ }^{*} p<0.05$. 
immunomodulatory and pro-angiogenic protein profile, reflecting MSC properties (Ward et al., 2018). Notably, the microtissue-SVF secreted substantially higher PGE2 levels, which is a major mediator of MSC immunomodulation (Gao et al., 2016; Kota et al., 2017). Successful adipose tissue formation can be observed with decellularised adipose tissue ECM combined with ASCs after 8 weeks in rats (Wang et al., 2013b). The regenerative macrophage-regulating interplay between MSCs and heart-tissue ECM can also be observed after decellularisation and reseeding of ECM scaffold in muscle regeneration (Qiu et al., 2018). In contrast, the gentle isolation procedure described resulted in therapeutic cells without dissociation and denaturation from the surrounding ECM, thereby making the procedure of decellularisation and reseeding redundant and providing a gently treated microtissue, which might positively influence a balanced M1/M2 macrophage response.

In fat grafting for cosmetic or reconstructive reasons, multiple strategies aim at generating a micronised homogenous tissue, which allows transplantation of an adipose matrix depleted of mature adipocytes. These strategies lead to improved volume retention lacking cysts and necrotic tissue (Li et al., 2017). Similar to the described approach, the enrichment of the SVF together with matrix and microvasculature may contribute substantially to the superior quality of these grafting materials (Feng et al., 2015; van Dongen et al., 2016). In comparison to the standard-SVF, the microtissue-SVF demonstrated a highly elevated potential to form tube-like structures in vitro, indicative of its angiogenic potential in vivo. The reason for the remarkable angiogenic potential may relate to the components of the micro vessels and capillaries (found in histology) that were preserved by the gentle isolation protocol. The interplay of vascular cells with ASCs and their secreted angiogenic factors
(Rohringer et al., 2014) give rise to a faster and more efficient angiogenic process (Pill et al., 2015). A high angiogenic potential is obligatory for successful graft integration and survival (Kakagia and Pallua, 2014; Luo et al., 2013). Luo et al. (2015) co-implant sorted endothelial cells from SVF with a fat graft in mouse leading to a high degree of vascularisation in a dosedependent manner. This is in concordance with the presented in vivo implantation experiment, showing that co-transplantation of the microtissue-SVF with fat resulted in vascularisation of the integrated graft.

Enhanced wound healing properties are demonstrated with a fat graft termed ECM/SVF-gel, secreting high MCP-1 and angiogenic factors (Liu et al., 2011; Sun et al., 2017), suggesting wound healing as another field of application for the microtissueSVF. A high angiogenic potential particularity predestines the material for regeneration of large areas of vascularised tissues, such as large skin defects and bone replacement (Jacobsen et al., 2008). SVF enhances bone formation due to its proangiogenic properties, as shown in a clinical study with natural scaffolds (Farre-Guasch et al., 2018). The microtissue-SVF as cell-loaded, pre-vascularised matrix could serve as graft or additive to vascularise newly developing tissue and reconnect vessels to host tissue. In myocardial regeneration, apart from vascularisation, also the mode of application of therapeutic cells and factors to the site of damage has raised problems. Intracoronary and intramyocardial injection of stem cells of different sources does not lead to the expected clinical outcome (Choudhury et al., 2017; Comella et al., 2016; Gyongyosi et al., 2015; Povsic et al., 2016) and application with biomaterials has limited success in clinical trials (Frey et al., 2014; Rao et al., 2015). As the microtissue-SVF is a cell-loaded hydrogel-like material, it might be a feasible material for application to the site of injury
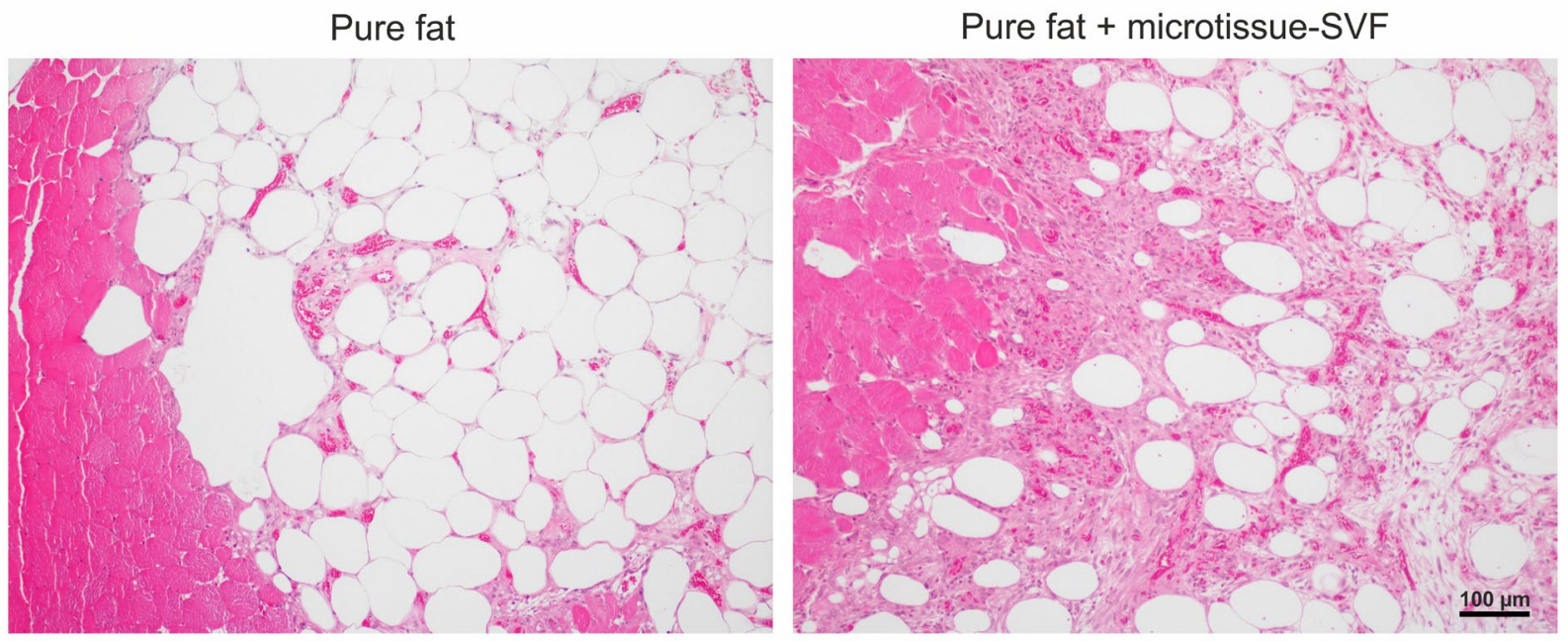

Fig. 7. In vivo implantation of pure-fat- and microtissue-SVF-supported fat graft. Pure fat either alone or in combination with the microtissue-SVF were intramuscularly injected into nude mice $(n=16)$ and showed better integration (connective tissue formation) and higher vascularisation in the presence of the microtissue-SVF. H\&E staining. Representative images. Scale bar $=100 \mu \mathrm{m}$. 

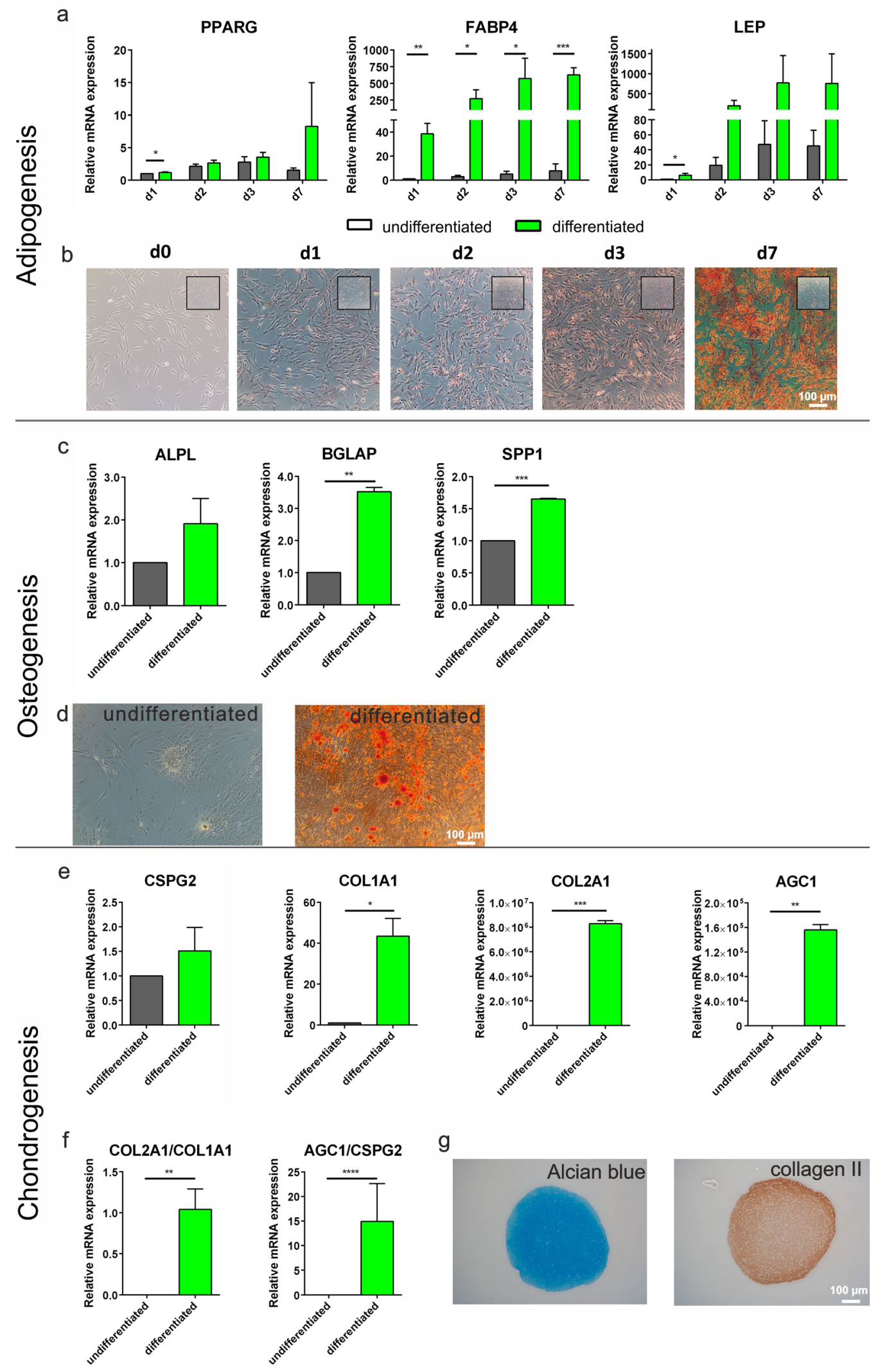

Fig. 8. Trilineage differentiation potential of the microtissue-SVF tested in vitro. Adipogenic $(n=3)$, osteogenic $(n=3)$ and chondrogenic $(n=2)$ differentiation potential of the microtissue-SVF adherent cells was compared to undifferentiated control cells. (a) qRT-PCR of the adipogenic markers, PPAR $\gamma$, FABP4 and LEP and (b) oil red O staining revealed the strong differentiation capacity of the microtissue-SVF-derived cells within days. (c) Expression of osteogenic marker genes, ALP, BGLAP and SPP1 and (d) alizarin red staining showed differentiation after $21 \mathrm{~d}$. (e) Chondrogenic differentiation after $35 \mathrm{~d}$ was demonstrated by qRT-PCR of CSPG2, COL1A1, COL2A1 and AGC1, (f) the differentiation index of COL2A1/ COL1A1 and AGC1/ CSPG2, as well as (g) alcian blue and collagen type II matrix staining. Data are shown as mean \pm SD. ${ }^{*} p<0.05 ;{ }^{* *} p<0.01 ;{ }^{* * *} p<0.001 ;{ }^{* * *} p<0.0001$. Representative images. Scale bar $=100 \mu \mathrm{m}$. 
and likewise delivering therapeutic cells and their secretome to the myocardium.

The increased immunomodulatory activity of the microtissue-SVF and the presence of regenerative cells predestine it for application in inflammatory disease with associated tissue damage. Since the microtissue-SVF further revealed a high chondrogenic differentiation potential (collagen type II and aggrecan expression and matrix deposition), it fulfils the requirements for application in osteoarthritis (OA). Previous approaches already show a therapeutic effect of either ASCs or SVF after intraarticular injection into the osteoarthritic joints (Jo et al., 2014; Pak et al., 2016a; Spasovski et al., 2017). The microtissue-SVF could be suitable to further improve the regenerative efficiency of SVFbased methods by direct application of the matrixentrapped cells to smoothen the rough surface and provide a temporal scaffold. The ECM protects the cells from direct impact by the surrounding tissues, which might increase the chance for survival and tissue regeneration. In contrast to similar approaches with current mechanical breakdown of the ECM (Pak et al., 2016b), the microtissue-SVF was minimally manipulated to reduce the stress on the cells (compression, shear force from preparation, pipetting and centrifugation) and to retain most possible bioactive composites. The ECM with its partially large collagen bundles provides a scaffolding effect and is especially predestined for applications such as strongly affected joints with large cartilage tissue loss.

In summary, a microtissue-SVF was developed from adipose tissue for intraoperative use by optimising an isolation protocol using GMP-grade reagents and procedures. The microtissue-SVF was rich in regenerative cells surrounded by intact vessels and endogenous ECM, creating a unique natural transplantable niche. This complex environment of ECM, SVF cells and their secretome potentially facilitates neovascularisation, immunomodulation and differentiation. The microtissue-SVF could provide a potent transplant for structural restoration of tissue defects for autologous clinical applications in regenerative medicine.

\section{Acknowledgements}

We would like to acknowledge Dr Hajnal Kiprov and Dr Matthias Sandhofer for providing liposuction material and valuable discussion. This work was funded by a grant from the Austrian Research Promotion Agency (FFG) (Bridge1 programme, grant number 846062).

Heinz Redl is cofounder of Liporegena. The other authors declare that they have no competing interests. The authors alone are responsible for the content and writing of the manuscript.

\section{References}

Aronowitz JA, Lockhart RA, Hakakian CS (2018) A method for isolation of stromal vascular fraction cells in a clinically relevant time frame. Methods Mol Biol 1773: 11-19.

Autengruber A, Gereke M, Hansen G, Hennig C, Bruder D (2012) Impact of enzymatic tissue disintegration on the level of surface molecule expression and immune cell function. Eur J Microbiol Immunol (Bp) 2: 112-120.

Bacakova L, Zarubova J, Travnickova M, Musilkova J, Pajorova J, Slepicka P, Kasalkova NS, Svorcik V, Kolska Z, Motarjemi H, Molitor M (2018) Stem cells: their source, potency and use in regenerative therapies with focus on adipose-derived stem cells - a review. Biotechnol Adv 36: 1111-1126.

Bateman ME, Strong AL, Gimble JM, Bunnell BA (2018) Using fat to fight disease: a systematic review of non-homologous adipose-derived stromal/stem cell therapies. Stem Cells 36: 1311-1328.

Bianchi F, Maioli M, Leonardi E, Olivi E, Pasquinelli G, Valente S, Mendez AJ, Ricordi C, Raffaini M, Tremolada C, Ventura C (2013) A new nonenzymatic method and device to obtain a fat tissue derivative highly enriched in pericyte-like elements by mild mechanical forces from human lipoaspirates. Cell Transplant 22: 2063-2077.

Bourin P, Bunnell BA, Casteilla L, Dominici M, Katz AJ, March KL, Redl H, Rubin JP, Yoshimura K, Gimble JM (2013) Stromal cells from the adipose tissue-derived stromal vascular fraction and culture expanded adipose tissue-derived stromal/stem cells: a joint statement of the International Federation for Adipose Therapeutics and Science (IFATS) and the International Society for Cellular Therapy (ISCT). Cytotherapy 15: 641-648.

Busser H, De Bruyn C, Urbain F, Najar M, Pieters K, Raicevic G, Meuleman N, Bron D, Lagneaux L (2014) Isolation of adipose-derived stromal cells without enzymatic treatment: expansion, phenotypical, and functional characterization. Stem Cells Dev 23: 23902400 .

Choudhury T, Mozid A, Hamshere S, Yeo C, Pellaton C, Arnous S, Saunders N, Brookman P, Jain A, Locca D, Archbold A, Knight C, Wragg A, Davies C, Mills P, Parmar M, Rothman M, Choudry F, Jones DA, Agrawal S, Martin J, Mathur A (2017) An exploratory randomized control study of combination cytokine and adult autologous bone marrow progenitor cell administration in patients with ischaemic cardiomyopathy: the REGENERATEIHD clinical trial. Eur J Heart Fail 19: 138-147.

Comella K, Parcero J, Bansal H, Perez J, Lopez J, Agrawal A, Ichim T (2016) Effects of the intramyocardial implantation of stromal vascular fraction in patients with chronic ischemic cardiomyopathy. J Transl Med 14: 158. DOI: 10.1186/ s12967-016-0918-5. 
Corselli M, Crisan M, Murray IR, West CC, Scholes J, Codrea F, Khan N, Peault B (2013) Identification of perivascular mesenchymal stromal/stem cells by flow cytometry. Cytometry A 83: 714-720.

De Francesco F, Ricci G, D'Andrea F, Nicoletti GF, Ferraro GA (2015) Human adipose stem cells: from bench to bedside. Tissue Eng Part B Rev 21: 572-584.

De Francesco F, Tirino V, Desiderio V, Ferraro G, D'Andrea F, Giuliano M, Libondi G, Pirozzi G, De Rosa A, Papaccio G (2009) Human CD34/CD90 ASCs are capable of growing as sphere clusters, producing high levels of VEGF and forming capillaries. PLoS One 4: e6537. DOI: 10.1371/journal.pone.0006537.

Dykstra JA, Facile T, Patrick RJ, Francis KR, Milanovich S, Weimer JM, Kota DJ (2017) Concise review: fat and furious: harnessing the full potential of adipose-derived stromal vascular fraction. Stem Cells Transl Med 6: 1096-1108.

Eto H, Kato H, Suga H, Aoi N, Doi K, Kuno S, Yoshimura K (2012) The fate of adipocytes after nonvascularized fat grafting: evidence of early death and replacement of adipocytes. Plast Reconstr Surg 129: 1081-1092.

European Medicines Agency (2012) Scientific recommendation on classification of advanced therapy medicinal products. Article 17 - Regulation (EC) No 1394/2007.

Farre-Guasch E, Bravenboer N, Helder MN, Schulten E, Ten Bruggenkate CM, Klein-Nulend J (2018) Blood vessel formation and bone regeneration potential of the stromal vascular fraction seeded on a calcium phosphate scaffold in the human maxillary sinus floor elevation model. Materials (Basel) 11: pii: E161. DOI: 10.3390/ma11010161.

Feng J, Doi K, Kuno S, Mineda K, Kato H, Kinoshita K, Kanayama K, Mashiko T, Yoshimura K (2015) Micronized cellular adipose matrix as a therapeutic injectable for diabetic ulcer. Regen Med 10: 699-708.

Frey N, Linke A, Suselbeck T, Muller-Ehmsen J, Vermeersch P, Schoors D, Rosenberg M, Bea F, Tuvia S, Leor J (2014) Intracoronary delivery of injectable bioabsorbable scaffold (IK-5001) to treat left ventricular remodeling after ST-elevation myocardial infarction: a first-in-man study. Circ Cardiovasc Interv 7: 806-812.

Fu Y, Karbaat L, Wu L, Leijten J, Both SK, Karperien M (2017) Trophic effects of mesenchymal stem cells in tissue regeneration. Tissue Eng Part B Rev 23: 515-528.

Gao F, Chiu SM, Motan DA, Zhang Z, Chen L, Ji HL, Tse HF, Fu QL, Lian Q (2016) Mesenchymal stem cells and immunomodulation: current status and future prospects. Cell Death Dis 7: e2062. DOI: 10.1038/cddis.2015.327.

Gentile P, Orlandi A, Scioli MG, Di Pasquali C, Bocchini I, Cervelli V (2012) Concise review: adiposederived stromal vascular fraction cells and plateletrich plasma: basic and clinical implications for tissue engineering therapies in regenerative surgery. Stem Cells Transl Med 1: 230-236.
Geutjes PJ, van der Vliet JA, Faraj KA, de Vries N, van Moerkerk HT, Wismans RG, Hendriks T, Daamen WF, van Kuppevelt TH (2010) Preparation and characterization of injectable fibrillar type I collagen and evaluation for pseudoaneurysm treatment in a pig model. J Vasc Surg 52: 1330-1338.

Gimble J, Guilak F (2003a) Adipose-derived adult stem cells: isolation, characterization, and differentiation potential. Cytotherapy 5: 362-369.

Gimble JM, Guilak F (2003b) Differentiation potential of adipose derived adult stem (ADAS) cells. Curr Top Dev Biol 58: 137-160.

Guo J, Nguyen A, Banyard DA, Fadavi D, Toranto JD, Wirth GA, Paydar KZ, Evans GR, Widgerow AD (2016) Stromal vascular fraction: a regenerative reality? Part 2: mechanisms of regenerative action. J Plast Reconstr Aesthet Surg 69: 180-188.

Gyongyosi M, Wojakowski W, Lemarchand P, Lunde K, Tendera M, Bartunek J, Marban E, Assmus B, Henry TD, Traverse JH, Moye LA, Surder D, Corti R, Huikuri H, Miettinen J, Wohrle J, Obradovic S, Roncalli J, Malliaras K, Pokushalov E, Romanov A, Kastrup J, Bergmann MW, Atsma DE, Diederichsen A, Edes I, Benedek I, Benedek T, Pejkov H, Nyolczas N, Pavo N, Bergler-Klein J, Pavo IJ, Sylven C, Berti S, Navarese EP, Maurer G, Investigators A (2015) MetaAnalysis of Cell-based CaRdiac stUdiEs (ACCRUE) in patients with acute myocardial infarction based on individual patient data. Circ Res 116: 1346-1360.

Hagman DK, Kuzma JN, Larson I, Foster-Schubert KE, Kuan LY, Cignarella A, Geamanu E, Makar KW, Gottlieb JR, Kratz M (2012) Characterizing and quantifying leukocyte populations in human adipose tissue: impact of enzymatic tissue processing. J Immunol Methods 386: 50-59.

Holnthoner W, Hohenegger K, Husa AM, Muehleder S, Meinl A, Peterbauer-Scherb A, Redl H (2015) Adipose-derived stem cells induce vascular tube formation of outgrowth endothelial cells in a fibrin matrix. J Tissue Eng Regen Med 9: 127-136.

Jacobsen KA, Al-Aq1 ZS, Wan C, Fitch JL, Stapleton SN, Mason ZD, Cole RM, Gilbert SR, Clemens TL, Morgan EF, Einhorn TA, Gerstenfeld LC (2008) Bone formation during distraction osteogenesis is dependent on both VEGFR1 and VEGFR2 signaling. J Bone Miner Res 23: 596-609.

Jiang A, Li M, Duan W, Dong Y, Wang Y (2015) Improvement of the survival of human autologous fat transplantation by adipose-derived stem-cells-assisted lipotransfer combined with bFGF. ScientificWorldJournal 2015: 968057. DOI: 10.1155/2015/968057.

Jiang T, Xu G, Wang Q, Yang L, Zheng L, Zhao J, Zhang X (2017) In vitro expansion impaired the stemness of early passage mesenchymal stem cells for treatment of cartilage defects. Cell Death Dis 8: e2851. DOI: 10.1038/cddis.2017.215.

Jo CH, Lee YG, Shin WH, Kim H, Chai JW, Jeong EC, Kim JE, Shim H, Shin JS, Shin IS, Ra JC, Oh S, Yoon KS (2014) Intra-articular injection of mesenchymal stem cells for the treatment of osteoarthritis of the 
knee: a proof-of-concept clinical trial. Stem Cells 32: 1254-1266.

Kakagia D, Pallua N (2014) Autologous fat grafting: in search of the optimal technique. Surg Innov 21: 327-336.

Kapur SK, Katz AJ (2013) Review of the adipose derived stem cell secretome. Biochimie 95: 2222-2228.

Katagiri H, Kushida Y, Nojima M, Kuroda Y, Wakao S, Ishida K, Endo F, Kume K, Takahara T, Nitta H, Tsuda H, Dezawa M, Nishizuka SS (2016) A distinct subpopulation of bone marrow mesenchymal stem cells, muse cells, directly commit to the replacement of liver components. Am J Transplant 16: $468-483$.

Kim BS, Choi JS, Kim JD, Choi YC, Cho YW (2012) Recellularization of decellularized human adiposetissue-derived extracellular matrix sheets with other human cell types. Cell Tissue Res 348: 559-567.

Kober J, Gugerell A, Schmid M, Zeyda M, Buchberger E, Nickl S, Hacker S, Ankersmit HJ, Keck M (2016) Wound healing effect of conditioned media obtained from adipose tissue on human skin cells: a comparative in vitro study. Ann Plast Surg 77: 156-163.

Kota DJ, Prabhakara KS, Toledano-Furman N, Bhattarai D, Chen Q, DiCarlo B, Smith P, Triolo F, Wenzel PL, Cox CS, Jr., Olson SD (2017) Prostaglandin E2 indicates therapeutic efficacy of mesenchymal stem cells in experimental traumatic brain injury. Stem Cells 35: 1416-1430.

Kuroda Y, Dezawa M (2014) Mesenchymal stem cells and their subpopulation, pluripotent muse cells, in basic research and regenerative medicine. Anat Rec (Hoboken) 297: 98-110.

Kuroda Y, Kitada M, Wakao S, Nishikawa K, Tanimura Y, Makinoshima H, Goda M, Akashi H, Inutsuka A, Niwa A, Shigemoto T, Nabeshima Y, Nakahata T, Nabeshima Y, Fujiyoshi Y, Dezawa M (2010) Unique multipotent cells in adult human mesenchymal cell populations. Proc Natl Acad Sci U S A 107: 8639-8643.

Li K, Li F, Li J, Wang H, Zheng X, Long J, Guo W, Tian W (2017) Increased survival of human free fat grafts with varying densities of human adiposederived stem cells and platelet-rich plasma. J Tissue Eng Regen Med 11: 209-219.

Lin CS, Ning H, Lin G, Lue TF (2012) Is CD34 truly a negative marker for mesenchymal stromal cells? Cytotherapy 14: 1159-1163.

Liu S, Zhang H, Zhang X, Lu W, Huang X, Xie H, Zhou J, Wang W, Zhang Y, Liu Y, Deng Z, Jin Y (2011) Synergistic angiogenesis promoting effects of extracellular matrix scaffolds and adipose-derived stem cells during wound repair. Tissue Eng Part A 17: 725-739.

Luo S, Hao L, Li X, Yu D, Diao Z, Ren L, Xu H (2013) Adipose tissue-derived stem cells treated with estradiol enhance survival of autologous fat transplants. Tohoku J Exp Med 231: 101-110.

Luo X, Cao W, Xu H, Wang L, Zhang Z, Lu Y, Jin X, Ren X, He J, Fu M, Huang Y, Pi Q, Fan Z (2015) Coimplanted endothelial cells improve adipose tissue grafts' survival by increasing vascularization. J Craniofac Surg 26: 358-364.

Lutfi D LL, Zeyda M, Stulnig T, Singer CF, Turkof E (2018) Centrifugation of adipose tissue aspirate causes endothelial cell enrichment. J Stem Cell Res Med 3. DOI: 10.15761/JSCRM.1000126.

Macrin D, Joseph JP, Pillai AA, Devi A (2017) Eminent sources of adult mesenchymal stem cells and their therapeutic imminence. Stem Cell Rev 13: 741-756.

McIntosh K1, Zvonic S, Garrett S, Mitchell JB, Floyd ZE, Hammill L, Kloster A, Di Halvorsen Y, Ting JP, Storms RW, Goh B, Kilroy G, Wu X, Gimble JM (2006) The immunogenicity of human adiposederived cells: temporal changes in vitro. Stem Cells 24: 1246-1253.

Mitchell JB, McIntosh K, Zvonic S, Garrett S, Floyd ZE, Kloster A, Di Halvorsen Y, Storms RW, Goh B, Kilroy G, Wu X, Gimble JM (2006) Immunophenotype of human adipose-derived cells: temporal changes in stromal-associated and stem cell-associated markers. Stem Cells 24: 376-385.

National Research Council (US) Committee for the Update of the Guide for the Care and Use of Laboratory Animals (2011) Guide for the care and use of laboratory animals, $8^{\text {th }}$ edition. National Academies Press, Washington, DC, USA.

Nguyen A, Guo J, Banyard DA, Fadavi D, Toranto JD, Wirth GA, Paydar KZ, Evans GR, Widgerow AD (2015) Stromal vascular fraction: a regenerative reality? Part 1: current concepts and review of the literature. J Plast Reconstr Aesthet Surg 69: 170-179.

Oberbauer E, Steffenhagen C, Wurzer C, Gabriel C, Redl H, Wolbank S (2015) Enzymatic and nonenzymatic isolation systems for adipose tissuederived cells: current state of the art. Cell Regen (Lond) 4: 7. DOI: 10.1186/s13619-015-0020-0.

Pak J, Lee JH, Kartolo WA, Lee SH (2016a) Cartilage regeneration in human with adipose tissue-derived stem cells: current status in clinical implications. Biomed Res Int 2016: 4702674. DOI: 10.1155/2016/4702674.

Pak J, Lee JH, Park KS, Jeong BC, Lee SH (2016b) Regeneration of cartilage in human knee osteoarthritis with autologous adipose tissue-derived stem cells and autologous extracellular matrix. Biores Open Access 5: 192-200.

Pak J, Lee JH, Pak N, Pak Y, Park KS, Jeon JH, Jeong BC, Lee SH (2018) Cartilage regeneration in humans with adipose tissue-derived stem cells and adipose stromal vascular fraction cells: updated status. Int J Mol Sci 19. DOI: 10.3390/ijms19072146.

Pan Q, Fouraschen SM, de Ruiter PE, Dinjens WN, Kwekkeboom J, Tilanus HW, van der Laan LJ (2014) Detection of spontaneous tumorigenic transformation during culture expansion of human mesenchymal stromal cells. Exp Biol Med (Maywood) 239: 105-115.

Pill K, Hofmann S, Redl H, Holnthoner W (2015) Vascularization mediated by mesenchymal stem cells from bone marrow and adipose tissue: a comparison. Cell Regen (Lond) 4: 8. DOI: 10.1186/s13619-015-0025-8. 
Povsic TJ, Henry TD, Traverse JH, Fortuin FD, Schaer GL, Kereiakes DJ, Schatz RA, Zeiher AM, White CJ, Stewart DJ, Jolicoeur EM, Bass T, Henderson DA, Dignacco P, Gu Z, Al-Khalidi HR, Junge C, Nada A, Hunt AS, Losordo DW, Investigators R (2016) The RENEW Trial: efficacy and safety of intramyocardial autologous CD34(+) cell administration in patients with refractory angina. JACC Cardiovasc Interv 9: 1576-1585.

Priglinger E, Maier J, Chaudary S, Lindner C, Wurzer C, Rieger S, Redl H, Wolbank S, Dungel P (2018) Photobiomodulation of freshly isolated human adipose tissue-derived stromal vascular fraction cells by pulsed light-emitting diodes for direct clinical application. J Tissue Eng Regen Med 12: 1352-1362.

Priglinger E, Schuh C, Steffenhagen C, Wurzer C, Maier J, Nuernberger S, Holnthoner W, Fuchs C, Suessner S, Runzler D, Redl H, Wolbank S (2017) Improvement of adipose tissue-derived cells by low-energy extracorporeal shock wave therapy. Cytotherapy 19: 1079-1095.

Prockop DJ (2007) "Stemness" does not explain the repair of many tissues by mesenchymal stem/ multipotent stromal cells (MSCs). Clin Pharmacol Ther 82: 241-243.

Qiu X, Liu S, Zhang H, Zhu B, Su Y, Zheng C, Tian R, Wang M, Kuang H, Zhao X, Jin Y (2018) Mesenchymal stem cells and extracellular matrix scaffold promote muscle regeneration by synergistically regulating macrophage polarization toward the M2 phenotype. Stem Cell Res Ther 9: 88 . DOI: 10.1186/s13287-018-0821-5.

Rao SV, Zeymer U, Douglas PS, Al-Khalidi H, Liu J, Gibson CM, Harrison RW, Joseph DS, Heyrman R, Krucoff MW (2015) A randomized, double-blind, placebo-controlled trial to evaluate the safety and effectiveness of intracoronary application of a novel bioabsorbable cardiac matrix for the prevention of ventricular remodeling after large ST-segment elevation myocardial infarction: rationale and design of the PRESERVATION I trial. Am Heart J 170: 929937.

Raposio E, Simonacci F, Perrotta RE (2017) Adipose-derived stem cells: comparison between two methods of isolation for clinical applications. Ann Med Surg (Lond) 20: 87-91.

Rohringer S, Hofbauer P, Schneider KH, Husa AM, Feichtinger G, Peterbauer-Scherb A, Redl H, Holnthoner W (2014) Mechanisms of vasculogenesis in 3D fibrin matrices mediated by the interaction of adipose-derived stem cells and endothelial cells. Angiogenesis 17: 921-933.

Safwani WK, Makpol S, Sathapan S, Chua KH (2013) Alteration of gene expression levels during osteogenic induction of human adipose derived stem cells in long-term culture. Cell Tissue Bank 14: 289301.

Salgado AJ, Reis RL, Sousa NJ, Gimble JM (2010) Adipose tissue derived stem cells secretome: soluble factors and their roles in regenerative medicine. Curr Stem Cell Res Ther 5: 103-110.
Scherberich A, Di Maggio ND, McNagny KM (2013) A familiar stranger: CD34 expression and putative functions in SVF cells of adipose tissue. World J Stem Cells 5: 1-8.

Seaman SA, Tannan SC, Cao Y, Peirce SM, Lin KY (2015) Differential effects of processing time and duration of collagenase digestion on human and murine fat grafts. Plast Reconstr Surg 136: 189e-199e.

Sidney LE, Branch MJ, Dunphy SE, Dua HS, Hopkinson A (2014) Concise review: evidence for CD34 as a common marker for diverse progenitors. Stem Cells 32: 1380-1389.

Spasovski D, Spasovski V, Bascarevic Z, Stojiljkovic M, Vreca M, Andelkovic M, Pavlovic S (2017) Intraarticular injection of autologous adipose-derived mesenchymal stem cells in the treatment of knee osteoarthritis. J Gene Med 20. DOI: 10.1002/jgm.3002.

Stivers KB, Beare JE, Chilton PM, Williams SK, Kaufman CL, Hoying JB (2017) Adipose-derived cellular therapies in solid organ and vascularizedcomposite allotransplantation. Curr Opin Organ Transplant 22: 490-498.

Sun M, He Y, Zhou T, Zhang P, Gao J, Lu F (2017) Adipose extracellular matrix/stromal vascular fraction gel secretes angiogenic factors and enhances skin wound healing in a murine model. Biomed Res Int 2017: 3105780. DOI: 10.1155/2017/3105780.

van Dongen JA, Stevens HP, Parvizi M, van der Lei B, Harmsen MC (2016) The fractionation of adipose tissue procedure to obtain stromal vascular fractions for regenerative purposes. Wound Repair Regen 24: 994-1003.

Wang L, Johnson JA, Zhang Q, Beahm EK (2013a) Combining decellularized human adipose tissue extracellular matrix and adipose-derived stem cells for adipose tissue engineering. Acta Biomater 9: 89218931.

Wang X, Wang Y, Gou W, Lu Q, Peng J, Lu S (2013b) Role of mesenchymal stem cells in bone regeneration and fracture repair: a review. Int Orthop 37: 2491-2498.

Ward MR, Abadeh A, Connelly KA (2018) Concise review: rational use of mesenchymal stem cells in the treatment of ischemic heart disease. Stem Cells Transl Med 7: 543-550.

Yoshimura K, Sato K, Aoi N, Kurita M, Hirohi T, Harii K (2008) Cell-assisted lipotransfer for cosmetic breast augmentation: supportive use of adiposederived stem/stromal cells. Aesthetic Plast Surg 32: 48-57.

Zimmerlin L, Donnenberg VS, Pfeifer ME, Meyer EM, Peault B, Rubin JP, Donnenberg AD (2010) Stromal vascular progenitors in adult human adipose tissue. Cytometry A 77: 22-30.

Zuk PA, Zhu M, Ashjian P, De Ugarte DA, Huang JI, Mizuno H, Alfonso ZC, Fraser JK, Benhaim P, Hedrick MH (2002) Human adipose tissue is a source of multipotent stem cells. Mol Biol Cell 13: 4279-4295.

Zuk PA, Zhu M, Mizuno H, Huang J, Futrell JW, Katz AJ, Benhaim P, Lorenz HP, Hedrick MH (2001) Multilineage cells from human adipose tissue: 
implications for cell-based therapies. Tissue Eng 7: 211-228.

Zwierzina ME, Ejaz A, Bitsche M, Blumer MJ, Mitterberger MC, Mattesich M, Amann A, Kaiser A, Pechriggl EJ, Horl S, Rostek U, Pierer G, Fritsch H, Zwerschke W (2015) Characterization of DLK1(PREF1)+/CD34+ cells in vascular stroma of human white adipose tissue. Stem Cell Res 15: 403418 .

\section{Discussion with Reviewer}

Giovanna Desando: What was the biological mechanism of action of the microtissue-SVF to foster tissue regeneration?

Authors: The microtissue-SVF was a fat derivative, a SVF without dissociation from its natural extracellular matrix. According to the in vitro findings, it was especially rich in regenerative, viable cells with a high differentiation and vascularisation potential and protected by endogenous matrix. The cells displayed parameters associated with immunomodulatory, pro-angiogenic and anti-inflammatory behaviour. All of which might contribute to its regenerative potential in tissue regeneration. The association with their extracellular matrix might further contribute to a better integration and survival after transplantation. These beneficial properties might allow the therapeutic cells to fulfil the desired purpose at each respective location.

Giovanna Desando: What could be the main clinical application in using the microtissue-SVF fraction? Authors: Any clinical application that requires local application of SVF would be recommended, especially interesting are soft tissue regeneration, wound healing and OA. Previous approaches reveal that MSCs or SVFs have a beneficial effect in OA scores when injected intraarticularly into the osteoarthritic joints (Jo et al., 2014, additional reference; Pak et al., 2016; Spasovski et al., 2018, additional reference). This effect is attributed to their immunomodulatory and anti-inflammatory properties. The microtissue-SVF contained highly viable matrix-protected cells, which might protect the cells in the local joint environment. The in vitro data further suggested a high immunomodulatory, anti-inflammatory and chondrogenic potential. Due to these in vitro pro-regenerative properties, the microtissue-SVF has the potential to act as improved cell therapy in OA.

Giovanna Desando: Do the authors think that the use of only secretome from the microtissue-SVF could represent a good therapeutic strategy?

Authors: The microtissue-SVF appeared to be rich in regenerative cells and could be a potent source for secretome of immunomodulatory, pro-angiogenic and anti-inflammatory factors or extracellular vesicles. However, the specific concept of the microtissue-SVF was that the preserved extracellular matrix not only limited manipulation during isolation but also protected the cellular components after delivering to regenerative sites and should, hence, be especially useful as cell therapeutic.

\section{Additional References}

Jo CH, Lee YG, Shin WH, Kim H, Chai JW, Jeong EC, Kim JE, Shim H, Shin JS, Shin IS, Ra JC, Oh S, Yoon KS. Intra-articular injection of mesenchymal stem cells for the treatment of osteoarthritis of the knee: a proof-of-concept clinical trial. Stem Cells 32: 1254-1266.

Spasovski D, Spasovski V, BaščarevićZ, Stojiljković M, Vreća M, Anđelković M, Pavlović S (2018) Intraarticular injection of autologous adipose-derived mesenchymal stem cells in the treatment of knee osteoarthritis. J Gene Med 20. DOI: 10.1002/jgm.3002.

Editor's note: The Scientific Editor responsible for this paper was Chris Evans. 